\title{
Turmeric and its bioactive constituents trigger cell signaling mechanisms that protect against diabetes and cardiovascular diseases
}

\author{
Huiying Amelie Zhang ${ }^{1}$ (D) David D. Kitts ${ }^{1}$ (])
}

Received: 19 February 2021 / Accepted: 27 May 2021 / Published online: 9 June 2021

(c) The Author(s), under exclusive licence to Springer Science+Business Media, LLC, part of Springer Nature 2021

\begin{abstract}
Turmeric, the rhizome of Curcuma longa plant belonging to the ginger family Zingiberaceae, has a history in Ayurvedic and traditional Chinese medicine for treatment of chronic diseases, including metabolic and cardiovascular diseases (CVD). This parallels a prevalence of age- and lifestyle-related diseases, especially CVD and type 2 diabetes (T2D), and associated mortality which has occurred in recent decades. While the chemical composition of turmeric is complex, curcuminoids and essential oils are known as two major groups that display bioactive properties. Curcumin, the most predominant curcuminoid, can modulate several cell signaling pathways involved in the etiology and pathogenesis of CVD, T2D, and related morbidities. Lesser bioactivities have been reported from other curcuminoids and essential oils. This review examines the chemical compositions of turmeric, and related bioactive constituents. A focus was placed on the cellular and molecular mechanisms that underlie the protective effects of turmeric and turmeric-derived compounds against diabetes and CVD, compiled from the findings obtained with cell-based and animal models. Evidence from clinical trials is also presented to identify potential preventative and therapeutic efficacies. Clinical studies with longer intervention durations and specific endpoints for assessing health outcomes are warranted in order to fully evaluate the long-term protective efficacy of turmeric.
\end{abstract}

Keywords Curcumin $\cdot$ Curcuminoids $\cdot$ Turmeric oil $\cdot$ Diabetes $\cdot$ Cardiovascular diseases $\cdot$ Human clinical trials

\begin{tabular}{|c|c|c|c|}
\hline \multicolumn{2}{|c|}{ Abbreviations } & Bax & Bcl-2-associated X protein \\
\hline $2 \mathrm{DG}$ & 2-Deoxyglucose & $\mathrm{Bcl}-2$ & B-cell lymphoma-2 \\
\hline \multirow[t]{2}{*}{ ABCA-1 } & Adenosine triphosphate (ATP)-binding & BDMC & Bisdemethoxycurcumin \\
\hline & cassette transporter A1 & $\beta-\mathrm{MHC}$ & Beta-myosin heavy chain \\
\hline AGE & Advanced glycation end-product & BMI & Body mass index \\
\hline Akt & Protein kinase B & BNP & Brain natriuretic peptide \\
\hline \multirow[t]{2}{*}{ AMPK } & 5' Adenosine monophosphate-activated & CABG & Coronary artery bypass grafting \\
\hline & protein kinase & CAT & Catalase \\
\hline ANF & Atrial natriuretic factor & CD36 & Cluster of differentiation 36 \\
\hline Ang II & Angiotensin II & CD68 & Cluster of differentiation 68 \\
\hline \multirow[t]{2}{*}{$\mathrm{aP2}$} & Adipocyte Protein 2 (aka. fatty acid-bind- & $\mathrm{C} / \mathrm{EBP}$ & CCAAT/enhancer-binding protein \\
\hline & ing protein 4, FABP4) & $\mathrm{CHOP}$ & C/EBP homologous protein \\
\hline ApoAI & Apolipoprotein AI & CK-MB & Creatine kinase-MB \\
\hline $\mathrm{ApoE}^{-/-}$ & Apolipoprotein E knockout & CRP & C-reactive protein \\
\hline \multirow[t]{2}{*}{ ATP } & Adenosine triphosphate & CVD & Cardiovascular diseases \\
\hline & & $\mathrm{DMC}$ & Demethoxycurcumin \\
\hline \multirow{2}{*}{\multicolumn{2}{|c|}{$\begin{array}{l}\triangle \text { David D. Kitts } \\
\text { david.kitts@ubc.ca }\end{array}$}} & DSPN & Diabetic sensorimotor polyneuropathy \\
\hline & & ECM & Extracellular matrix \\
\hline \multirow{3}{*}{\multicolumn{2}{|c|}{$\begin{array}{l}\text { Huiying Amelie Zhang } \\
\text { amelie.huiying.zhang@ubc.ca }\end{array}$}} & $\mathrm{ER}$ & Endoplasmic reticulum \\
\hline & & ERK1/2 & Extracellular signal-regulated kinase $1 / 2$ \\
\hline & & FBS & Fasting blood sugar \\
\hline \multirow[b]{2}{*}{$\begin{array}{l}\text { System } \\
\text { Canada }\end{array}$} & on and Health, Faculty of Land and Food & FFAR & Free fatty acid receptor \\
\hline & University of British Columbia, Vancouver, & FOXO3a & Forkhead box O3a \\
\hline
\end{tabular}




\begin{tabular}{|c|c|c|c|}
\hline G6P & Glucose 6-phosphate & $\mathrm{PIP}_{2}$ & Phosphatidylinositol-4,5-bisphosphate \\
\hline GATA4 & GATA-binding factor 4 & $\mathrm{PIP}_{3}$ & Phosphatidylinositol-3,4,5-trisphosphate \\
\hline GCK & Glucokinase & p.o. & Oral administration (Latin per os) \\
\hline GLP-1 & Glucagon-like peptide -1 & PPAR- $\gamma$ & Peroxisome proliferator-activated \\
\hline GLUT & Glucose transporter & & receptor- $\gamma$ \\
\hline GPR & G-protein-coupled receptor & $\mathrm{RCT}$ & Randomized clinical trials \\
\hline GR & Glutathione reductase & SIRT-1 & Sirtuin-1 \\
\hline GSH-Px & Glutathione peroxidase & SOD & Superoxide dismutase \\
\hline GSIS & Glucose-stimulated insulin secretion & SP1 & Specific protein 1 \\
\hline HAT & Histone acetyltransferase & SR-A & Scavenger receptor class $\mathrm{A}$ \\
\hline $\mathrm{HbA1c}$ & Hemoglobin A1c (glycated hemoglobin) & SREBP & Sterol regulatory element-binding protein \\
\hline HDL-c & High-density lipoprotein cholesterol & STAT & Signal transducer and activator of \\
\hline HFD & High-fat diet & & transcription \\
\hline $\mathrm{H} / \mathrm{R}$ & Hypoxia/reoxygenation & $\mathrm{T} 2 \mathrm{D}$ & Type 2 diabetes \\
\hline hs-CRP & High-sensitivity C-reactive protein & TC & Total cholesterol \\
\hline ICAM-1 & Intercellular cell adhesion molecule-1 & TG & Triglyceride \\
\hline $\mathrm{I} \kappa \mathrm{B}$ & Inhibitor of NF- $\mathrm{NB}$ & TGF- $\beta 1$ & Transforming growth factor beta 1 \\
\hline $\mathrm{IL}$ & Interleukin & TLR & Toll-like receptor \\
\hline i.p. & Intraperitoneal injection & $\mathrm{TNF}-\alpha$ & Tumor necrosis factor $\alpha$ \\
\hline IR & Insulin receptor & VCAM-1 & Vascular cell adhesion molecule-1 \\
\hline $\mathrm{I} / \mathrm{R}$ & Ischemia/reperfusion & $\mathrm{VCP}$ & Valosin-containing protein \\
\hline IRS & Insulin receptor substrate & WC & Waist circumference \\
\hline JAK & Janus kinase & $\% \mathrm{BF}$ & Percent body fat \\
\hline
\end{tabular}

Keap1 Kelch-like ECH-associated protein 1

LC3 Microtubule-associated protein 1 light chain 3

LDH Lactate dehydrogenase

LDL Low-density lipoproteins

LDL-c Low-density lipoprotein cholesterol

LDL-R Low-density lipoprotein receptor

Lp(a) Lipoprotein a

LXR $\alpha \quad$ Liver X receptor $\alpha$

MAPK Mitogen-activated protein kinase

MCP-1 Mast cell protease 1

MDA Malondialdehyde

MetS Metabolic syndrome

MI Myocardial infarction

miR-7a/b MicroRNA-7a/b

MMP-2 Matrix metalloproteinase-2

NAD Nicotinamide adenine dinucleotide

NF-кB Nuclear factor kappa B

Nrf2 Nuclear factor erythroid 2-related factor 2

NT-pro-BNP N-terminal pro-B-type natriuretic peptide

oxLDL Oxidized low-density lipoproteins

PAB Pro-oxidant-antioxidant balance

PDK1 3-Phosphoinositide-dependent protein

kinase-1

PDX-1 Pancreatic and duodenal homeobox-1

p-ERK1/2 Extracellular signal-regulated kinase 1/2

PGC- $1 \alpha \quad$ Peroxisome proliferator-activated receptor- $\gamma$ coactivator- $1 \alpha$

PGN Peptidoglycan

PI3K Phosphatidylinositol-3-kinase

\section{Introduction}

Curcuma longa Linn. (Syn. Curcuma domestica Valeton) belongs to the ginger family Zingiberaceae, a perennial plant that grows in tropical and humid climates and originates from the Indian Subcontinent and Southeast Asia [1,2]. The term longa refers to the elongated shape of the rhizome, where turmeric is derived from the rhizome of the plant having a characteristic orange-yellow color. The term for turmeric varies among languages, but most often it refers to "yellow colour" or "bright colour" [3]. The Latin word curcuma is believed to be derived from the Arabic root kurkum meaning "saffron," in reference to similar coloring properties [4]. Turmeric is also known as "Indian saffron."

The history of using turmeric dates back to more than 4000 years during the Vedic age of India, where it was initially used as a dye and a culinary spice, due to its bright yellow color and aromatic flavor [2,3]. Turmeric also has a spiritual significance, where with the Hindu religion, turmeric was connected with South East Asian countries by $700 \mathrm{AD}$, migrating later to West and East African countries during 800 to $1200 \mathrm{AD}[2,3]$. Turmeric has become a commonly cultivated seed in many of these countries and regions. Along with the history of use, turmeric has had an important role in folk medicine, especially Ayurveda and traditional Chinese medicine where it was used as a remedy for various diseases that range from simple ailments to more complex chronic illnesses, such as digestive (e.g., abdominal 
pain and bloating, dyspepsia), cardiovascular (e.g., heart burning, heart pain), respiratory (e.g., runny nose, sinusitis, asthma), and hepatic disorders [1, 5-8]. On the other hand, turmeric although arriving in Europe in the 13th century by Arab traders currently remains a minor spice in Western countries. Until more recently, turmeric has been recognized, and since gained popularity as a dietary supplement and a nutraceutical thus becoming one of the most successful natural health products sold in the US since 2013 [9]. Recent studies that have also shown therapeutic potential of turmeric against coronavirus disease 2019 (COVID-19) [10] and the potential to modulate cytokine storm in COVID-19 patients [11] have produced formidable renewed interest in this herb.

Notwithstanding the long history of using turmeric in traditional medicine to treat various diseases, the mechanism or scientific basis for its bioactivity has remained unclear, until more recently when pharmacological assessments demonstrated safe use for modern medicine [3]. Curcuminoids and essential oils (mainly terpenoids) are two major components present in turmeric, the former being responsible for the orange-yellow color of the herb and the latter accounting for the aromatic flavor [12]. These components also possess a wide range of bioactivities (Table 1), for which evidence has been substantiated at all levels of inquiry that range from in vitro and in vivo experiments to human clinical studies $[12,13]$. Curcumin, a principal and abundant curcuminoid in turmeric, has been extensively studied for bioactivity in pharmaceutical studies [14]. Albeit a majority of preclinical and clinical studies have focused on the efficacy of turmeric extracts and isolated curcumin, relatively less information exists on bioactivity of other curcuminoids and essential

Table 1 Major bioactivities of turmeric and its bioactive constituents that relate to specific health disorders

\begin{tabular}{llc}
\hline Health disorder & Reported bioactivity & References \\
\hline Oxidative stress & Antioxidant & {$[15-18]$} \\
Inflammation and inflamma- & Anti-inflammatory & {$[19-21]$} \\
tory diseases & Immunomodulatory & \\
Allergy & Anti-allergic & {$[22-24]$} \\
Cardiovascular diseases & Hypolipidemic & {$[25-28]$} \\
& Atheroprotective & \\
Diabetes & Cardioprotective & \\
& Hypoglycemic & {$[29-32]$} \\
Cancer & Antiglycation & \\
& Antidiabetic & \\
& Antitumor & {$[33-36]$} \\
& Pro-apoptotic & \\
Neurodegenerative diseases & Antimetastatic & \\
Depression & Anticancer & Neuroprotective \\
Liver diseases & Antidepressant & {$[37-39]$} \\
\hline
\end{tabular}

oils present from turmeric for potential use in modern-day medicinal and nutraceutical industries [12].

Among the various bioactivities possessed by turmeric and its bioactive components listed in Table 1 [15-45], the antidiabetic and cardioprotective effects have attracted pronounced attention from numerous researchers with a common interest in understanding the role of turmeric and related bioactives in the protection against cardiovascular diseases (CVD), that currently exists as a leading cause of mortality worldwide. Diabetes is also one of the top 10 causes of death and is often associated with onset of CVD [46]. Although a number of therapeutic strategies for diabetes and CVD have been developed and tested, there are limited applications because of the high costs, low accessibility, and complications [14].

This review provides an overview on the complex chemical composition of turmeric and its bioactive constituents that are involved in metabolic health benefits. Furthermore, we review mechanistic preclinical (in vitro and in vivo) evidence on the antidiabetic and cardioprotective effects attributed to turmeric constituents. A comprehensive discussion on the cellular and molecular mechanisms that corroborates the beneficial outcomes observed from human clinical trials is given.

\section{Chemical composition of turmeric}

Proximate analysis (Fig. 1) of turmeric reveals that the herb contains 6-13\% moisture, with 60-70\% carbohydrate, 6-8\% protein, $5-10 \%$ fat, $3-7 \%$ minerals (potassium, sodium, calcium, iron, phosphorus), and trace amounts of vitamins [47-49]. Essential oils obtained by steam distillation represent $3-7 \%$ of the turmeric rhizome and mainly consist of terpenoids, including sesquiterpenoids (e.g., $\alpha$-phellandrene, zingiberene), monoterpenoids (e.g., sabinene, cineol), and norsesquiterpenoids $[12,49]$. There is also $3-5 \%$ curcuminoids, which comprises more than 50 structurally related compounds; the three principal ones being curcumin, demethoxycurcumin, and bisdemethoxycurcumin [47]. In general, turmeric composition varies according to the soil conditions used in cultivation, with Indian turmeric being regarded as having superior quality and high curcumin content [3]. Curcuminoids and essential oils are classified as secondary metabolites produced by Curcuma plants, with well-defined bioactivity [50].

\section{Curcuminoids}

Curcuminoids are bioactive phenolic compounds and consist of more than 100 individual curcuminoids that have been isolated and identified from genus Curcuma, about 50 of which are present in $C$. longa (turmeric). Turmeric contains 
Fig. 1 Composition of turmeric (C. longa) rhizome [47-49]

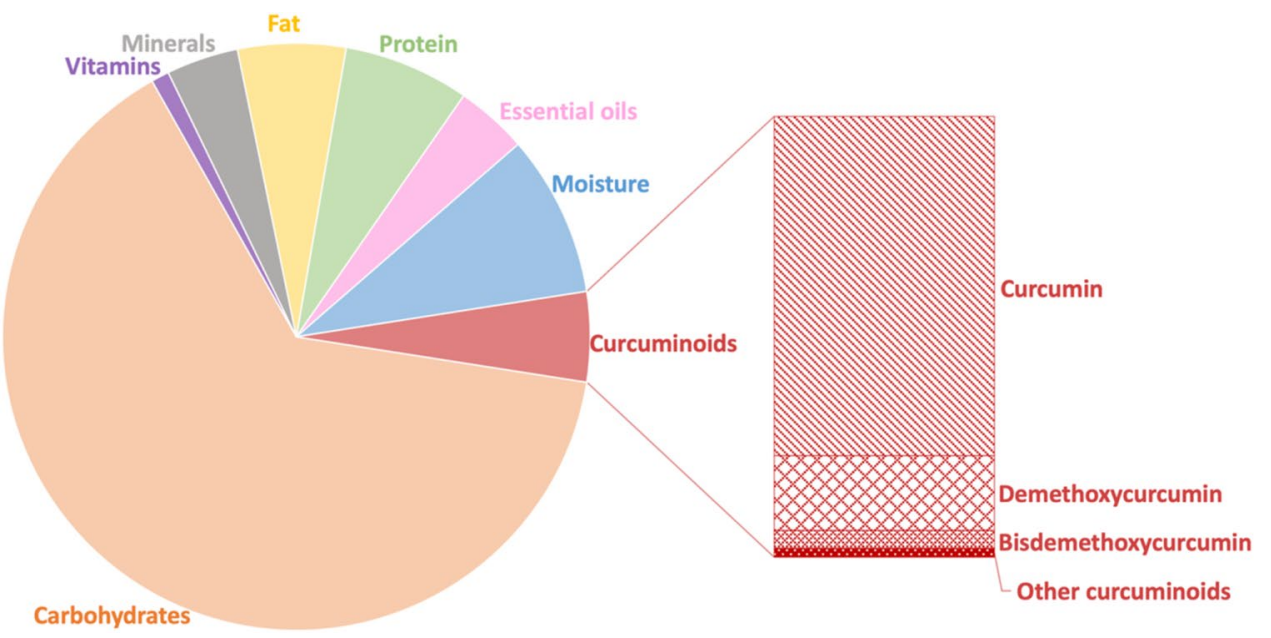

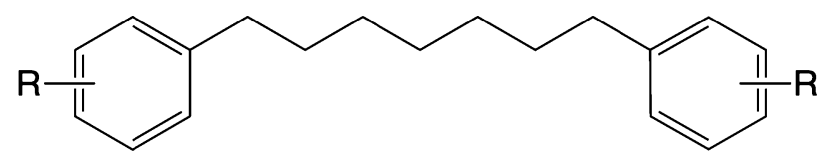

Fig. 2 Skeleton structure of diphenylheptanoids

three major curcuminoids: curcumin (CUR; 77\%), demethoxycurcumin (DMC; 17\%), and bisdemethoxycurcumin (BMC; 3-6\%) [12, 47].

Strictly speaking, curcuminoids only refer to linear diphenylheptanoids with a skeleton structure that has two aromatic rings linked by a heptane chain (Fig. 2) [51]. By this definition, there are 15 curcuminoids isolated and identified in turmeric $(C$. longa).

The definition of curcuminoids has expanded to include any orange-yellow-colored compounds present in turmeric that are structurally related to the principal constituent curcumin [51]. Specifically, there must be two aryl groups (aromatic rings) linked by an aliphatic chain, which is usually a heptane (7C) chain (Compounds 1-15), or a pentane (5C) chain (Compounds 16-18). Alternatively, a cyclic chain structure exists (Compounds 19-21). Cyclization of the heptane chain leads to the formation of a furanone ring, as shown in curcumalongin A and B (Compounds 20, 21), or a pyrone ring present in cyclcocurcumin (Compound 22). These are generally not common and found only in C. longa. The structures and names of these compounds are presented in Table 2 [52-56]. More recently, uncommon structures of curcuminoids that are conjugated with monoterpenes or sesquiterpenes have been isolated from turmeric and have been termed terpecurcuminoids or terpenoid-conjugated curcuminoids [57].

Curcuminoids are readily soluble in polar organic solvents, such as dimethyl sulfoxide (DMSO), acetone, methanol, and ethanol, but are poorly soluble in water, lipids, and hydrocarbons, like cyclohexane and hexane
[47, 58]. The 1,3-diketone group in curcumin and some curcuminoids (Compounds 1-8) exhibit keto-enol tautomerism, and therefore exist in keto and enol tautomeric forms (Fig. 3). The diketo form predominates in crystal curcumin or in acidic and neutral solutions, whereas the keto-enol form is exclusively present in alkaline conditions [47-49]. Water solubility increases under alkaline conditions when curcuminoids assume ionic forms upon dissociation of enolic and phenolic protons [47].

Curcuminoids are subject to chemical degradation in aqueous-organic solutions, especially under alkaline $\mathrm{pH}$, or in dilute solutions of curcuminoids. Binding to macromolecules, such as albumins, lipids, and liposomes, will increase curcuminoid stability $[59,60]$. Although the degradation mechanism is not fully understood, it is generally believed that hydrolysis of the $\alpha, \beta$-unsaturated $\beta$-diketone moiety, which is a common structure in curcuminoids, is involved in the reaction. Major degradation products of curcuminoids that have been identified include vanillin, vanillic acid, ferulic acid, ferulic aldehyde, and others [60].

An even more significant and rapid degradation of curcuminoids occurs when exposed to photooxidation, as is the case when curcuminoids are exposed to sunlight. Photochemical degradations of curcuminoids occur in both solid form and in solution $[58,60]$. The products of photodegradation are almost identical to those that are produced from chemical degradation, thereby indicating similar decomposition pathways. Photodegradation is initiated by photoexcitation resulting in the formation of triplet excited states of curcuminoids, which subsequently act as principal photosensitizers of singlet oxygen. The curcuminoids in turn undergo self-photosensitization, a reaction that is not dependent on the presence of oxygen $[60,61]$. To prevent photodegradation of curcuminoids from ultraviolet light sources, commercial products are typically packaged in brown or amber containers for shelf-storage. 


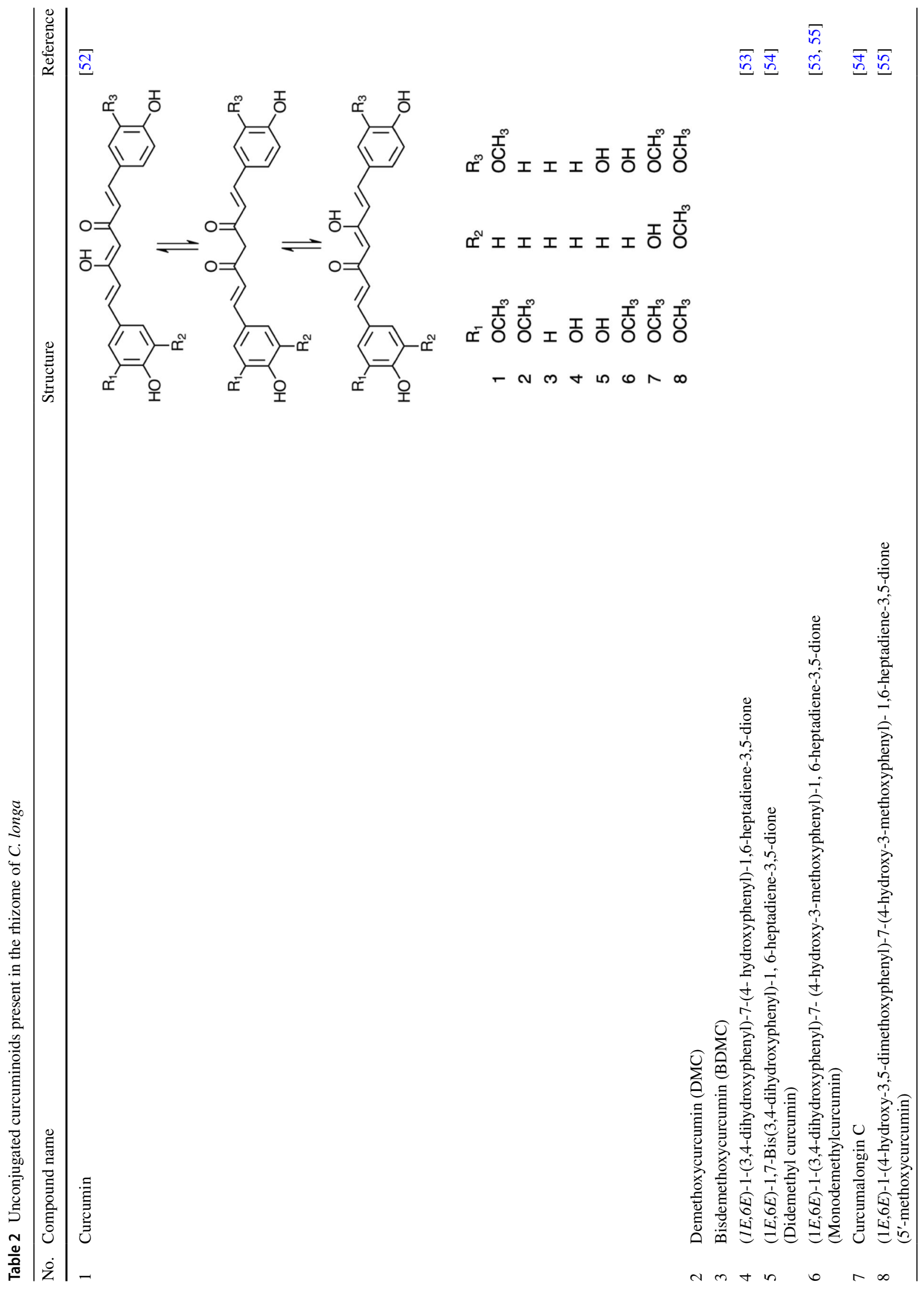




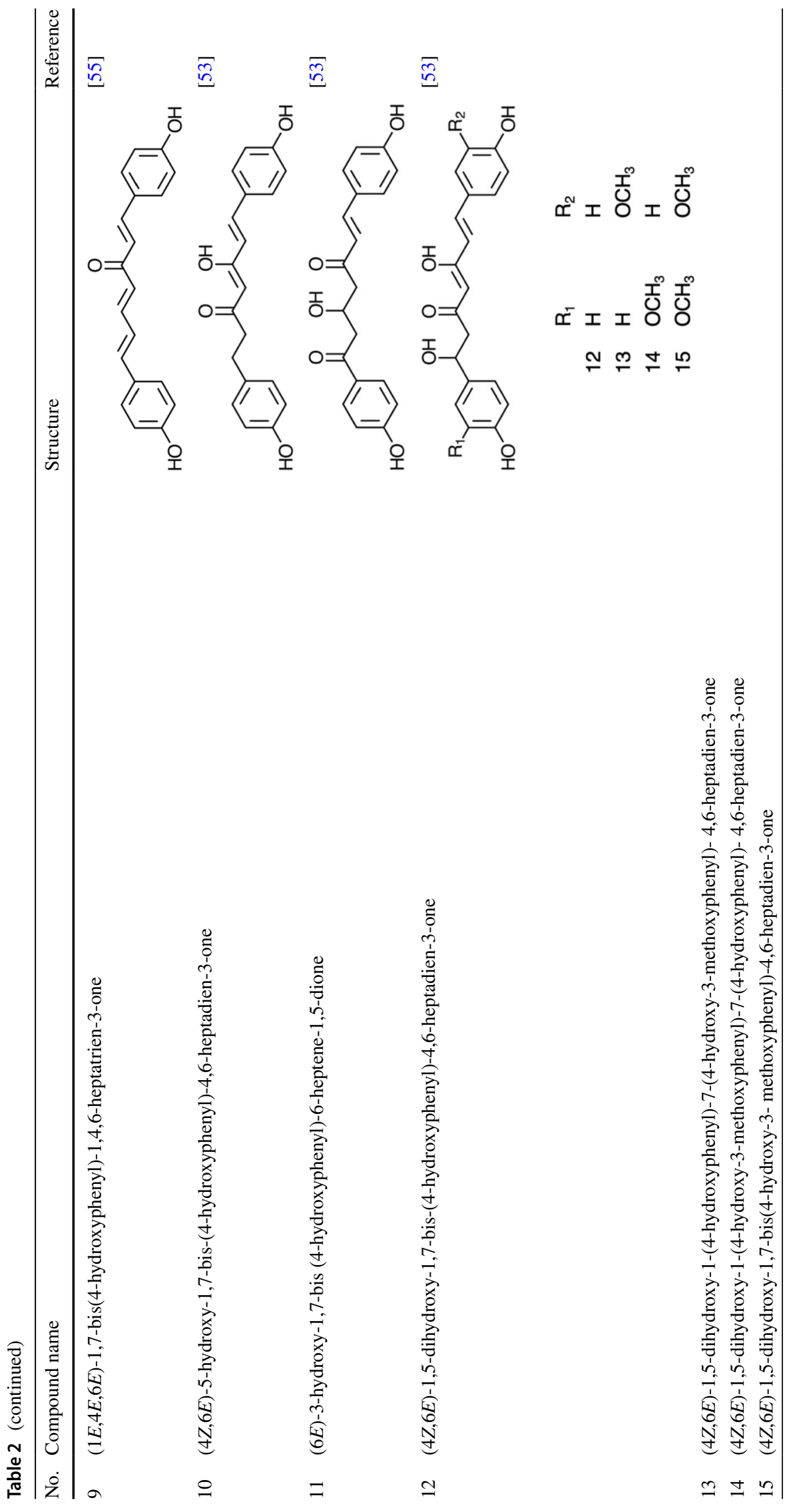




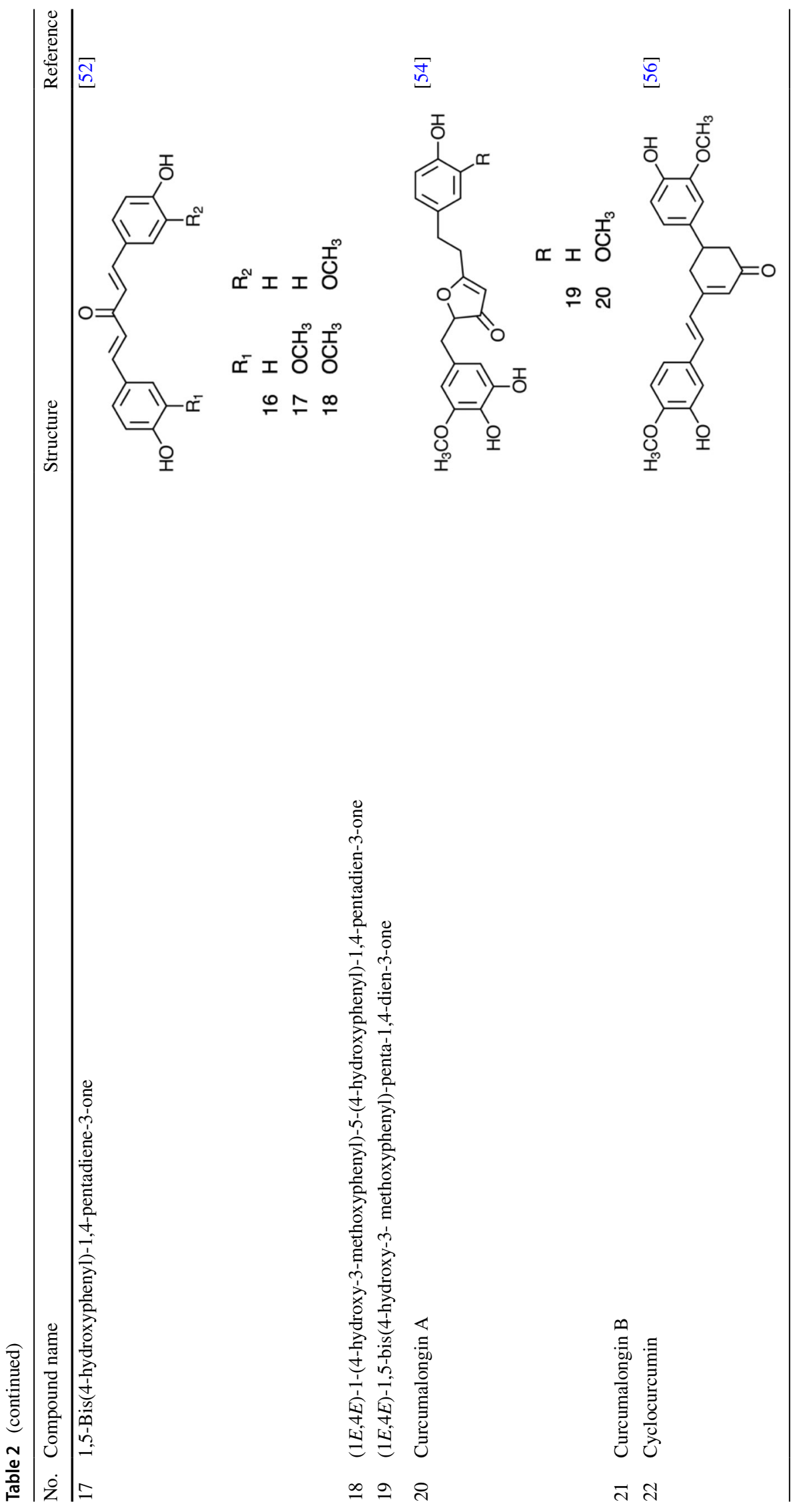




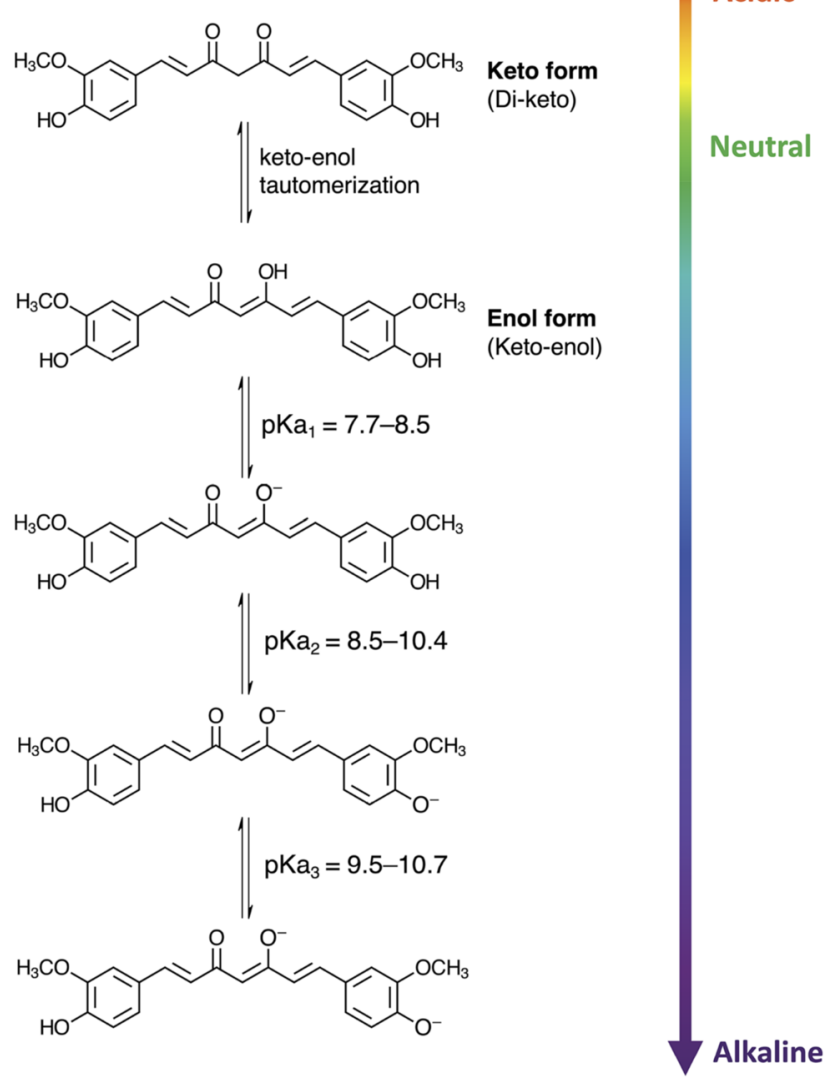

Fig. 3 Different forms of curcumin depending on $\mathrm{pH}$ conditions

Besides degradation, bioavailability of phytochemicals is also an important factor limiting pharmaceutical applications. The efficacy of curcumin toward antioxidant, anti-inflammatory, and anti-angiogenic activities is governed by factors that limits bioavailability, or accelerates metabolism and elimination. Low bioavailability of curcumin, due to its poor water solubility, has received considerable attention to find ways to enhance bioavailability using novel encapsulation delivery strategies that include liposomes, polymeric micelles, micro-emulsions, and nano-particle technologies [62-64]. Moreover, improved gastrointestinal absorption and bioavailability of curcumin has been observed using other plant bioactive components, such as piperine [65], and genistein [66] as adjuvants to increase permeability of curcumin, whereas tea catechins, namely, epigallocatechin-3-gallate-EGCG, are known to counteract certain curcumin activities [67].

\section{Turmeric oil (essential oils)}

Turmeric oil (TO) is a group of essential oils which mainly consists of more than 250 diverse terpenoids, identified from
Curcuma species [68]. TO represents another major group of bioactive compounds in turmeric. Table 3 summarizes the major and most commonly reported terpenoids isolated from turmeric (C. longa) [69-88], which have been categorized into sesquiterpenoids (Compounds 22-81), monoterpenoids (Compounds 82-86), norsesquiterpenoids (Compounds 87-89), and norditerpenes (Compound 90) [12].

Monoterpenes, with a molecular formula $\mathrm{C}_{10} \mathrm{H}_{16}$, consist of two isoprene units existing in either linear (acyclic) or ring structure (mono- or bi-cyclic) forms. Monoterpenoid derivatives are produced through modification, such as oxygenation or demethylation [51]. Sesquiterpenes, with a molecular formula $\mathrm{C}_{15} \mathrm{H}_{24}$, and associated sesquiterpenoid derivatives consist of three isoprenoid units. As is the case with monoterpenes and monoterpenoids, sesquiterpenes and sesquiterpenoids also exist in either acyclic or cyclic form [68]. Sesquiterpenoids are the dominant group of terpenoids in the turmeric rhizome and are further sub-categorized into several types; the major three being bisabolane, guaiane, and germacrane types, and the minor ones being carane, elemane, spironolactone types, and others [12]. Turmerones ( $\alpha, \beta$, and aromatic) that fall into the bisabolane-type sesquiterpene category are the predominant constituents that contribute to approximately $50 \%$ of the total TO [68]. A broad spectrum of biological activities has been reported in all the sesquiterpenoid classes.

\section{Terpecurcuminoids (terpenoid-conjugated curcuminoids)}

Terpecurcuminoids are a minor group of bioactive compounds recovered from turmeric and are distinguished by having a curcuminoid moiety that is conjugated with a terpenoid moiety [89-93]. Out of the 29 identified terpecurcuminoids (Compounds 91-119), 20 compounds have a curcumin moiety, while others possess DMC, BDMC, and curcuminoid derivatives; bisabolene-type sesquiterpenoids are the most common terpenoid moiety, existing in 24 terpecurcuminoids (Table 4). The curcuminoid and terpenoid moieties in 17 of these compounds are conjugated via one or two $\mathrm{C}-\mathrm{C}$ bonds, while in 12 compounds they are conjugated via $\mathrm{C}-\mathrm{O}-\mathrm{C}$ bonds $[92,93]$.

The terpecurcuminoids show cytotoxicity against various human cancer cell lines (e.g., human breast cancer cell lines MDA-MB-231 and MCF-7, human liver cancer cell line HepG2, and human lung cancer cell line A549), and some have exhibited greater cytotoxic potency compared to curcumin, thereby suggesting a promising anti-cancer activity of these compounds that requires more investigation on clinical efficacies $[89,90]$. 
Table 3 Terpenoids present in the rhizome of C. longa

\begin{tabular}{|c|c|c|}
\hline No. & Compound & Reference \\
\hline \multicolumn{3}{|c|}{ Sesquiterpenoids } \\
\hline \multicolumn{3}{|c|}{ Bisabolane-type sesquiterpenes } \\
\hline 22 & $\alpha$-turmerone & [69] \\
\hline 23 & $\beta$-turmerone & [69] \\
\hline 24 & Aromatic (ar)-turmerone & {$[70]$} \\
\hline 25 & ar-dihydroturmerone & [71] \\
\hline 26 & $\beta$-sesquiphellandrene & [72] \\
\hline 27 & ar-curcumene & [73] \\
\hline 28 & Curlone & {$[74]$} \\
\hline $29-32$ & Curculonone A-D & {$[75]$} \\
\hline 33 & $\beta$-atlantone & {$[75]$} \\
\hline $34-35$ & $(Z) /(E)$ - $\alpha$-atlantone & [76] \\
\hline 36 & $(6 \mathrm{~S}, 7 R)$-bisabolone & [76] \\
\hline 37 & $(6 R, 7 R)$-bisabolone & [77] \\
\hline 38 & $\beta$-bisabolene & {$[72]$} \\
\hline 39 & $\alpha$-zingiberene & {$[72]$} \\
\hline 40 & 2-methoxy-5-hydroxybisabola-3,10-diene-9-one & [78] \\
\hline 41 & 2,8-epoxy-5-hydroxybisabola-3,10-diene-9-one & [78] \\
\hline 42 & 4-methylene-5-hydroxybisabola-2,10-diene-9-one & [78] \\
\hline 43 & Bisacurone & [79] \\
\hline $44-46$ & Bisacurone A-C & [78] \\
\hline 47 & (6S)-2-hydroxy-6-(4-hydroxy-3-methylphenyl)-2-methylheptan-4-one & {$[80]$} \\
\hline 48 & (6S)-6-(4-hydroxy-3-methylphenyl)-2-methoxy-2-methylheptan-4-one & {$[80]$} \\
\hline \multicolumn{3}{|c|}{ Bisabolane-type sesquiterpenoids } \\
\hline $49-50$ & 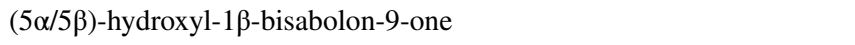 & [81] \\
\hline $51-52$ & Turmeronol A-B & [82] \\
\hline 53 & (6S)-2-methyl-6-(4-hydroxyphenyl)-2-hepten-4-one & [83] \\
\hline $54-57$ & Turmerone A-D & [84] \\
\hline 58 & Turmerone Q & {$[85]$} \\
\hline 59 & Bisabola-3,10-diene-2-one & [79] \\
\hline 60 & 2,5-dihydroxybisabola-3,10-diene & [79] \\
\hline 61 & 4,5-dihydroxybisabola-2,10-diene & [79] \\
\hline 62 & ar-tumerol (bisacumol) & [79] \\
\hline 63,64 & Longpene C, D & [86] \\
\hline 65 & Intermedin B & [86] \\
\hline \multicolumn{3}{|c|}{ Guaiane-type sesquiterpenoids } \\
\hline 66 & Curcumenol & [79] \\
\hline 67 & Procurcumadiol & [79] \\
\hline 68 & Procurcumenol & [79] \\
\hline 69 & Isoprocurcumenol & [79] \\
\hline 70 & Epiprocurcumenol & [79] \\
\hline 71 & Zedoaronediol & [79] \\
\hline 72 & 1,10-dehydro-10-deoxy-9-oxozedoarondiol & [75] \\
\hline \multicolumn{3}{|c|}{ Germacrane-type sesquiterpenoids } \\
\hline 73 & Dehydrocurdione & [79] \\
\hline 74 & Germacrone-13-al & [79] \\
\hline 75 & $(4 S, 5 S)$-germacrone-4,5-epoxide & [79] \\
\hline \multicolumn{3}{|c|}{ Carane-type sesquiterpenoid } \\
\hline 76 & Curcumenone & [79] \\
\hline
\end{tabular}


Table 3 (continued)

\begin{tabular}{|c|c|c|}
\hline No. & Compound & Reference \\
\hline \multicolumn{3}{|c|}{ Elemane-type sesquiterpenoid } \\
\hline 77 & Curzerenone & [86] \\
\hline \multicolumn{3}{|c|}{ Spironolactone-type sesquiterpenoid } \\
\hline 78 & 6 $\alpha$-hydroxycurcumanolide A & [75] \\
\hline \multicolumn{3}{|c|}{ Other sesquiterpenoids } \\
\hline 79 & Bicycloturmeronol & [87] \\
\hline 80 & Longpene B & [86] \\
\hline \multicolumn{3}{|c|}{ Novel sesquiterpene with new skeleton } \\
\hline 81 & (6S)-2-methyl-6-(4-hydroxy-3-methylphenyl)-2-hepten-4-one & [83] \\
\hline \multicolumn{3}{|c|}{ Monoterpenoids } \\
\hline \multicolumn{3}{|c|}{ Linear monoterpene } \\
\hline 82 & $(Z)$ - $\beta$-ocimene & {$[88]$} \\
\hline \multicolumn{3}{|c|}{ Monocyclic monoterpene } \\
\hline 83 & 2-(2,5-dihydroxy-4-methylcyclohex-3-enyl)-propanoic acid & [78] \\
\hline 84 & p-cymene & [77] \\
\hline \multicolumn{3}{|c|}{ Monocyclic monoterpenoid } \\
\hline 85 & 1,8-cineole & [77] \\
\hline \multicolumn{3}{|c|}{ Bicyclic monoterpenoid } \\
\hline 86 & $\alpha$-pinene & [77] \\
\hline \multicolumn{3}{|c|}{ Norsesquiterpenoids } \\
\hline 87 & 4-hydroxybisabola-2,10-diene-9-one & [79] \\
\hline 88 & 4-methoxy-5-hydroxybisabola-2, 10-diene-9-one & [79] \\
\hline 89 & $(6 R)$-[(1R)-1,5-dimethylhex-4-enyl]-3-methylcyclohex-2-en-1-one & [75] \\
\hline \multicolumn{3}{|c|}{ Norditerpene } \\
\hline 90 & Longpene A & [86] \\
\hline
\end{tabular}

Table 4 Terpecurcuminoids in the rhizome of C. longa

\begin{tabular}{|c|c|c|c|c|}
\hline No & Compound & Curcuminoid moiety & Terpenoid moiety & Reference \\
\hline \multicolumn{5}{|c|}{$\mathrm{C}-\mathrm{C}$ conjugation } \\
\hline 91 & Bisabocurcumin & Curcumin & Bisabolane-type sesquiterpenoid & {$[92]$} \\
\hline 92,93 & Terpercurcumin H, I & & & [89] \\
\hline $94-100$ & Terpercurcumin L-P, R, T & & & {$[90]$} \\
\hline 101 & Terpercurcumin Q & Curcumin & Other sesquiterpenoid & {$[90]$} \\
\hline 102 & Terpercurcumin X & Tetrahydrocurcumin & Bisabolane-type sesquiterpenoid & [91] \\
\hline 103 & Terpercurcumin Y & Cyclocurcumin & Bisabolane-type sesquiterpenoid & {$[91]$} \\
\hline 104,105 & Terpercurcumin $\mathrm{J}, \mathrm{K}$ & Dihydro-BDMC & Other sesquiterpenoid & {$[90]$} \\
\hline 106,107 & Terpercurcumin V, W & Curcumin & Monocyclic monoterpenoid & {$[90]$} \\
\hline \multicolumn{5}{|c|}{$\mathrm{C}-\mathrm{O}-\mathrm{C}$ conjugation } \\
\hline 108 & Bisabolocurcumin ether & Curcumin & Bisabolane-type sesquiterpenoid & {$[93]$} \\
\hline $109-114$ & Terpercurcumin A-F & & & [89] \\
\hline 115 & Demethoxybisabolo-curcumin ether & $\mathrm{DMC}$ & Bisabolane-type sesquiterpenoid & [93] \\
\hline 116 & Terpercurcumin G & & & [89] \\
\hline 117 & Terpercurcumin U & & & [91] \\
\hline 118 & Didemethoxybisabolo-curcumin ether & BDMC & Bisabolane-type sesquiterpenoid & [93] \\
\hline 119 & Terpercurcumin $\mathrm{S}$ & & & [91] \\
\hline
\end{tabular}




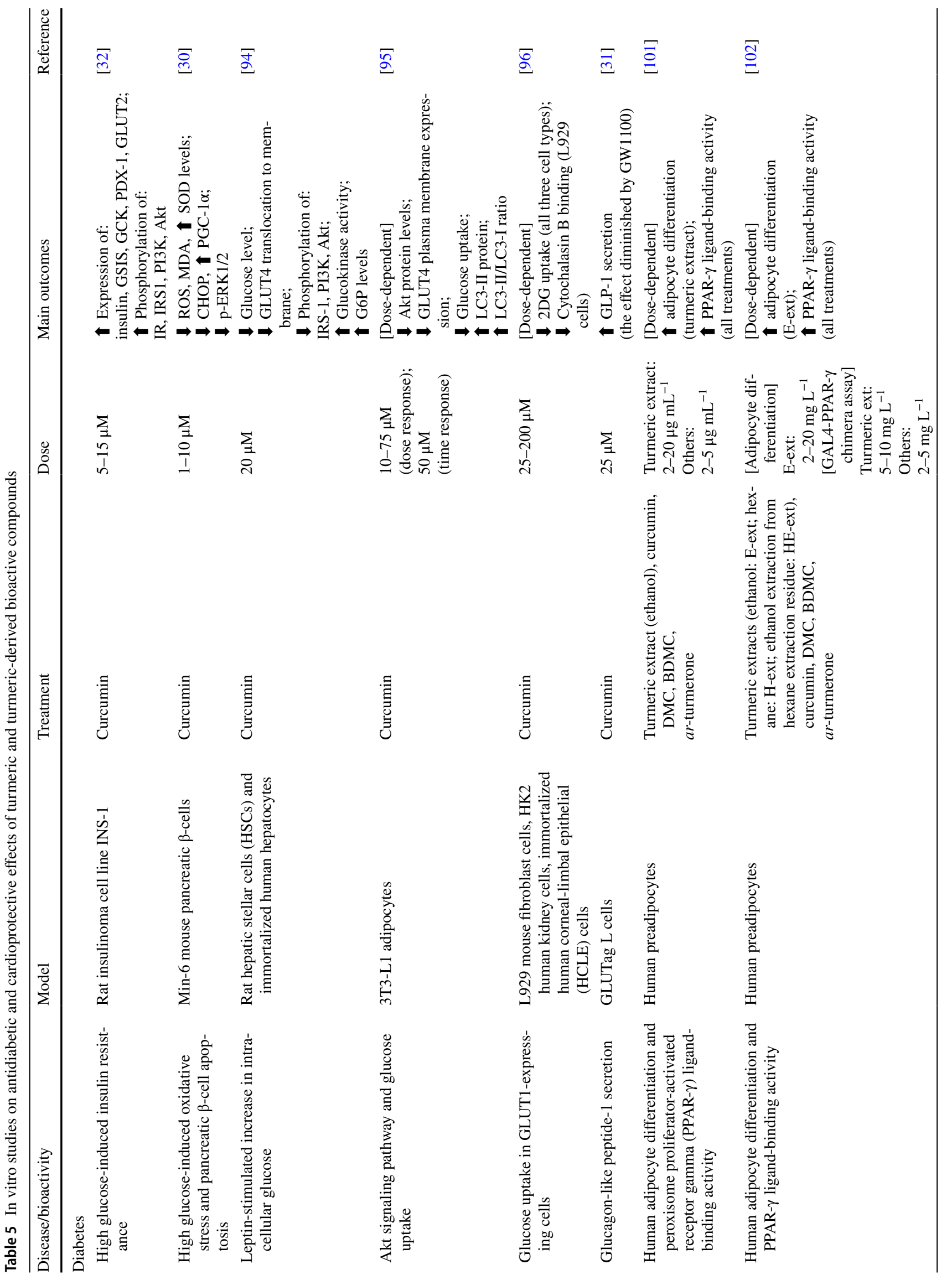




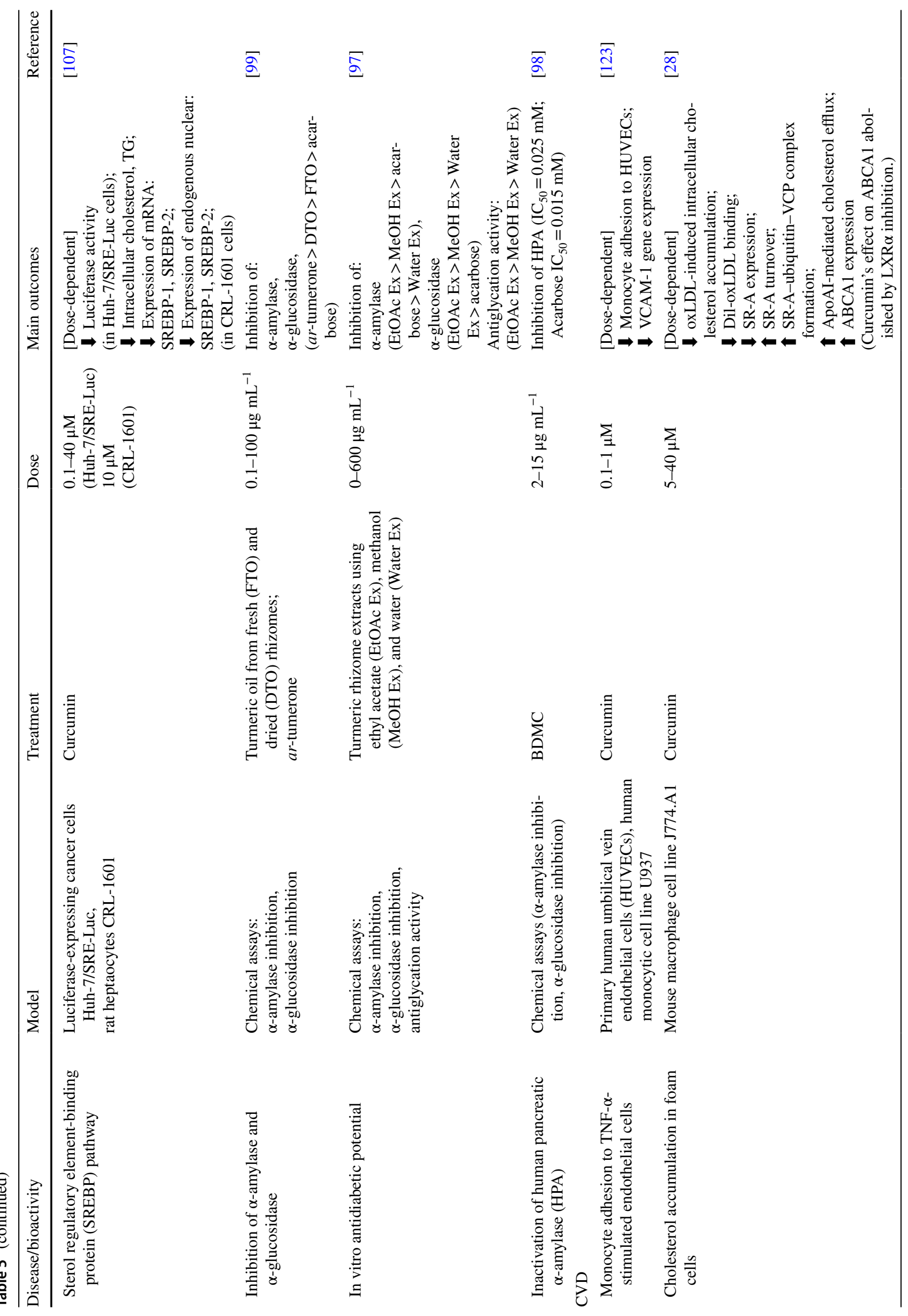




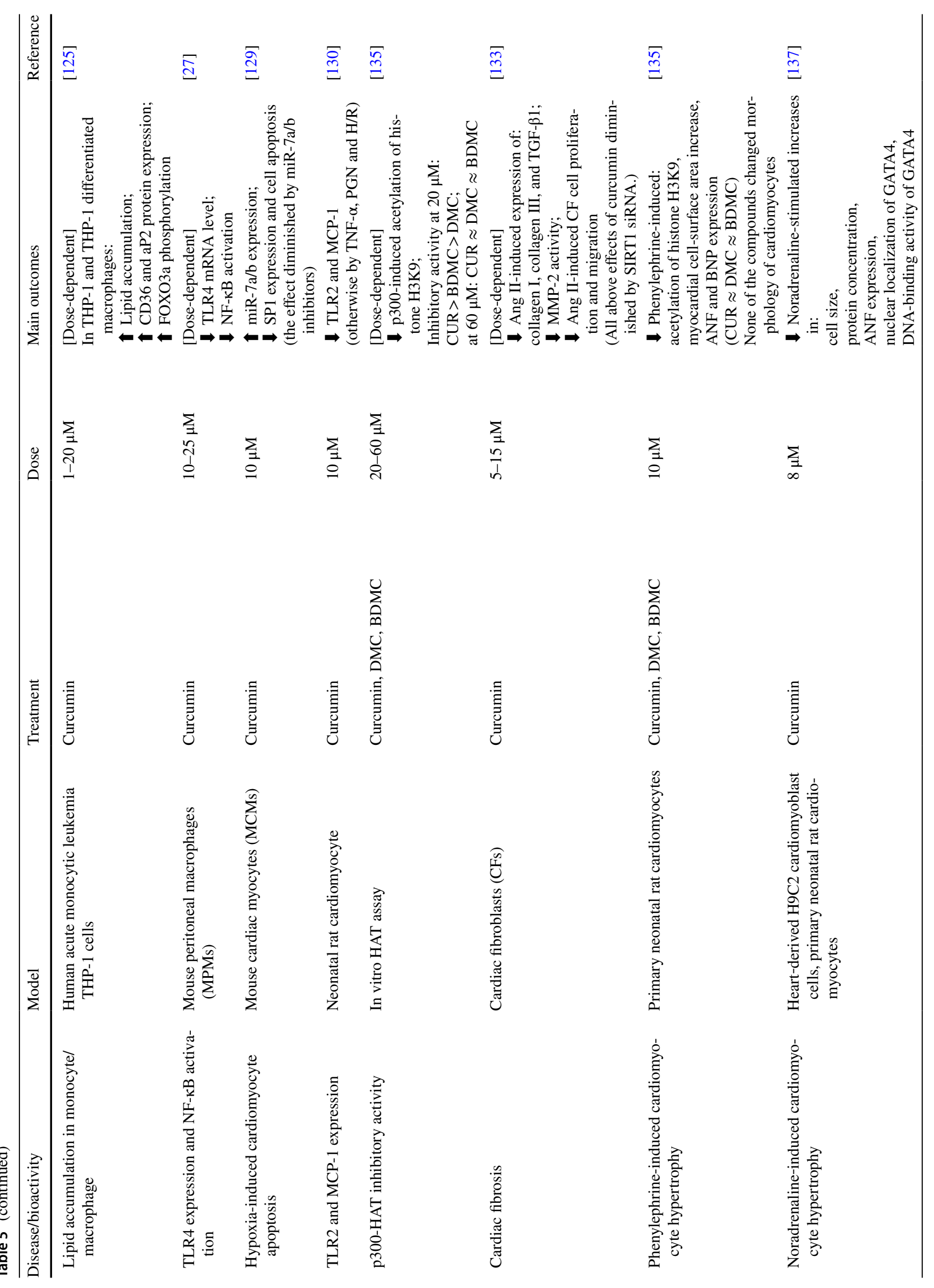




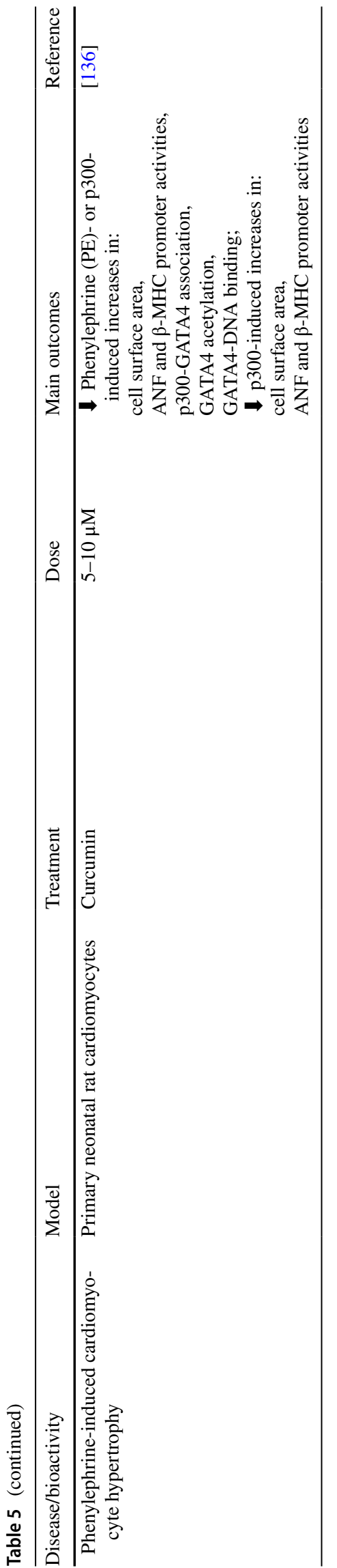

\section{Bioactivities of turmeric and its constituents against diabetes and CVD}

Cellular and molecular mechanisms of the bioactivities of turmeric and several constituents reported from both in vitro (Table 5) and in vivo studies (Table 6) point to chemoprotection against onset of chronic diseases, such as diabetes and CVD. Human clinical trials (Table 7) have also provided positive evidence to recognize clinical efficacy of turmeric and turmeric-derived compounds. Table 8 summarizes the few current meta-analyses that reported on clinical effects of these compounds against CVD and related conditions.

\section{Hypoglycemic and antidiabetic activities}

Curcumin and other related bioactive compounds present in turmeric have been proposed to protect against type 2 diabetes (T2D) through different mechanisms that involve a hypoglycemic effect attributed to upregulation of insulin, enhanced insulin sensitivity, and lower cellular uptake of glucose.

The mechanism of which curcumin evokes hypoglycemic and antidiabetic effects involves the pancreatic $\beta$-cells (Fig. 4). Curcumin attenuates high glucose-induced insulin resistance in cultured rat insulinoma cells, INS-1, a model by which insulin secretion by pancreatic $\beta$-cells has been studied [32]. The underlying mechanism therein is the increased expression and secretion of insulin by activating the phosphatidylinositol-3-kinase/protein kinase B/glucose transporter 2 (PI3K/Akt/GLUT2) signaling pathway. In this pathway, curcumin acts to upregulate phosphorylation of the insulin receptor (IR), insulin receptor substrate (IRS)-1, $\mathrm{PI} 3 \mathrm{~K}$, and Akt, all of which in turn increase the expression of pancreatic and duodenal homeobox-1 (PDX-1) and subsequent insulin mRNA. This effect is linked to increased levels of GLUT2 and glucokinase (GCK) activity, which are both required to regulate cellular glucose uptake and metabolism [32]. These processes are otherwise suppressed in the presence of a high glucose concentration. Curcumin is effective at attenuating oxidative stress that is induced by high glucose levels and which triggers apoptosis in a dose-dependent manner, and observation made using in mouse pancreatic $\beta$-cells [30]. This occurs by both a downregulated expression of C/EBP homologous protein (CHOP) and an upregulated expression of peroxisome proliferator-activated receptor- $\gamma$ coactivator- $1 \alpha$ (PGC-1 $\alpha$ ), along with a suppressing effect on phosphorylation of extracellular signal-regulated kinase 1/2 (ERK1/2) [30].

In adipocytes and hepatocytes, curcumin reduces glucose uptake by inhibiting the translocation of GLUT4 from the cytosol to plasma membrane, and by interfering with the 


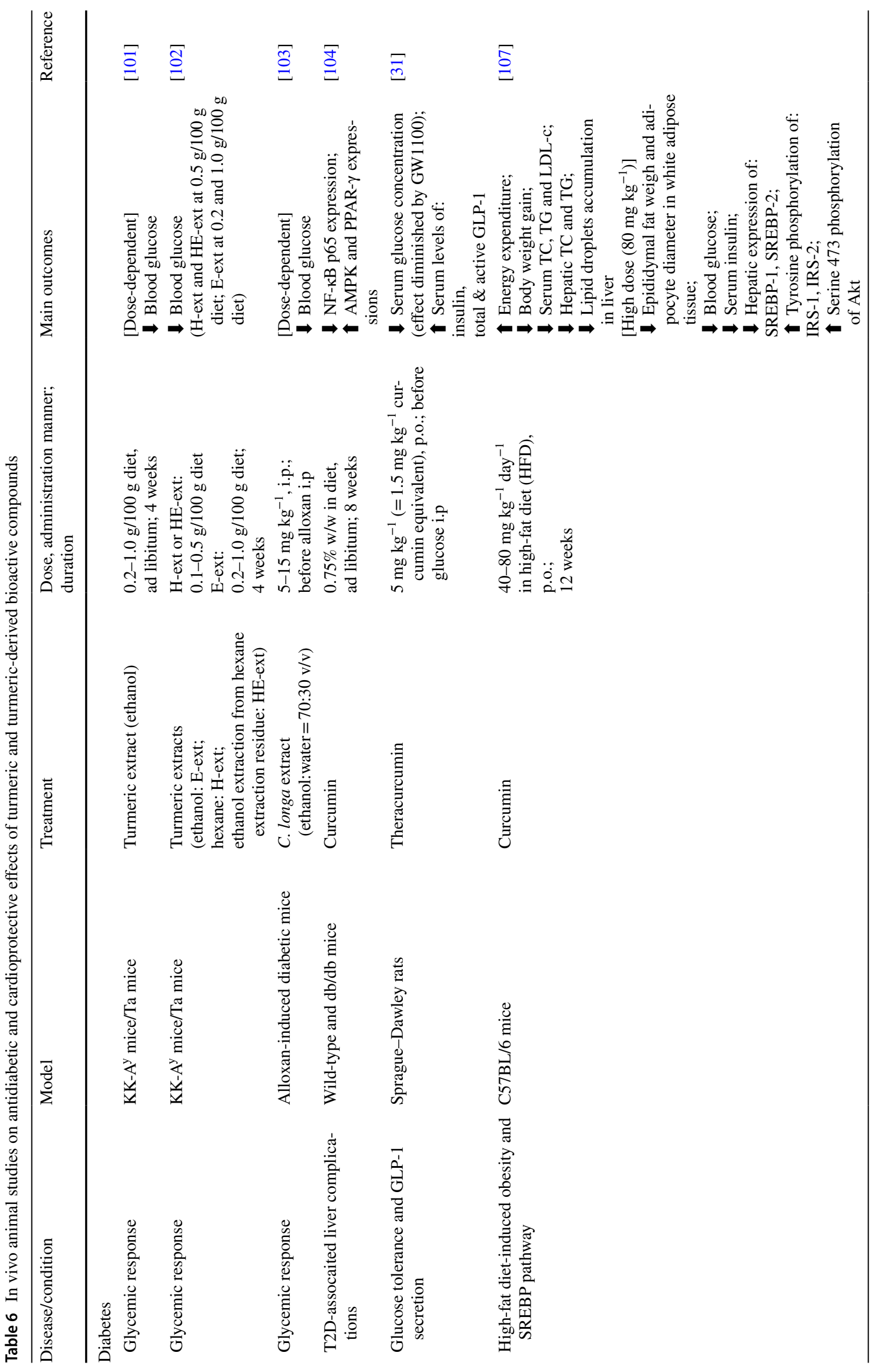




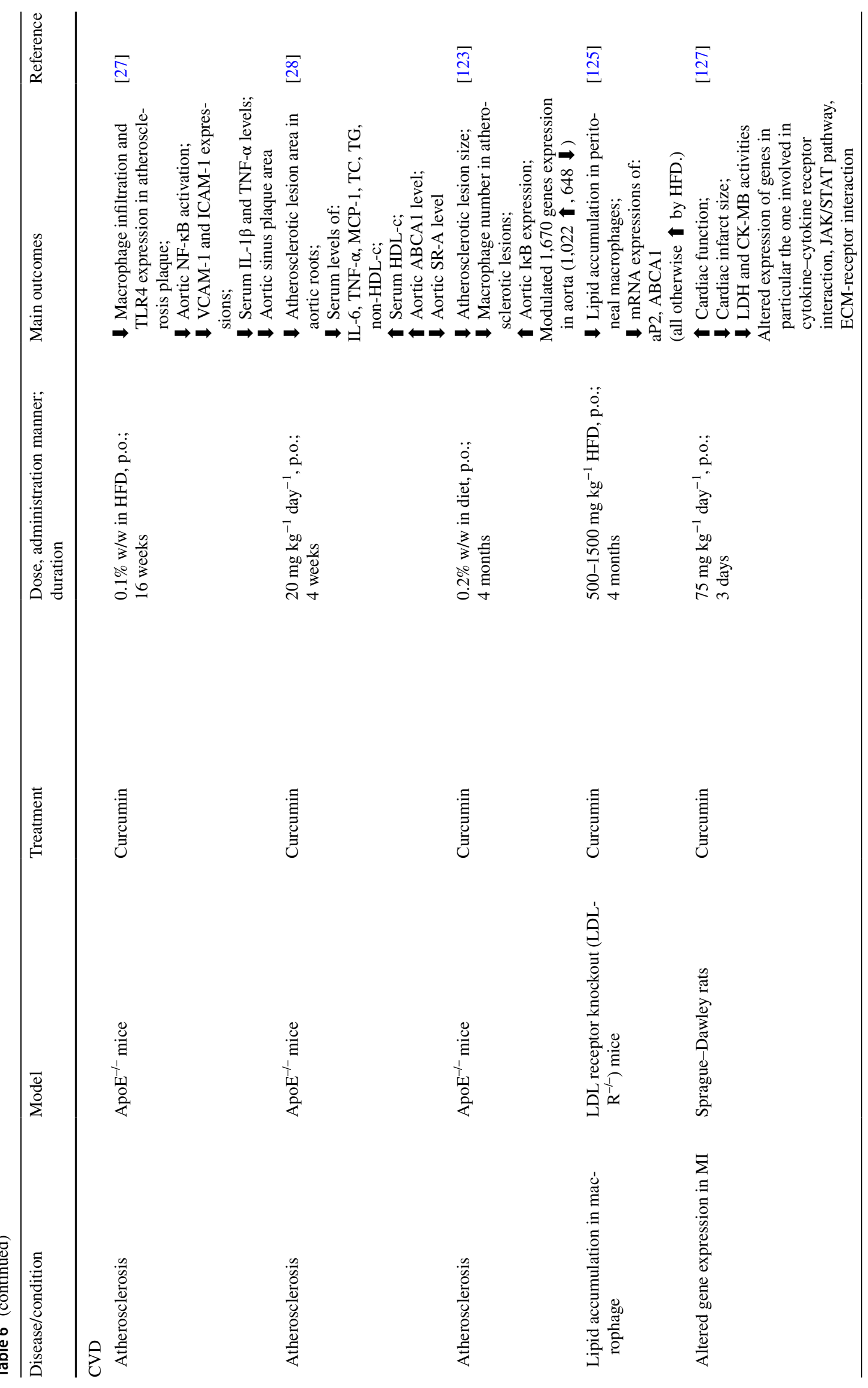




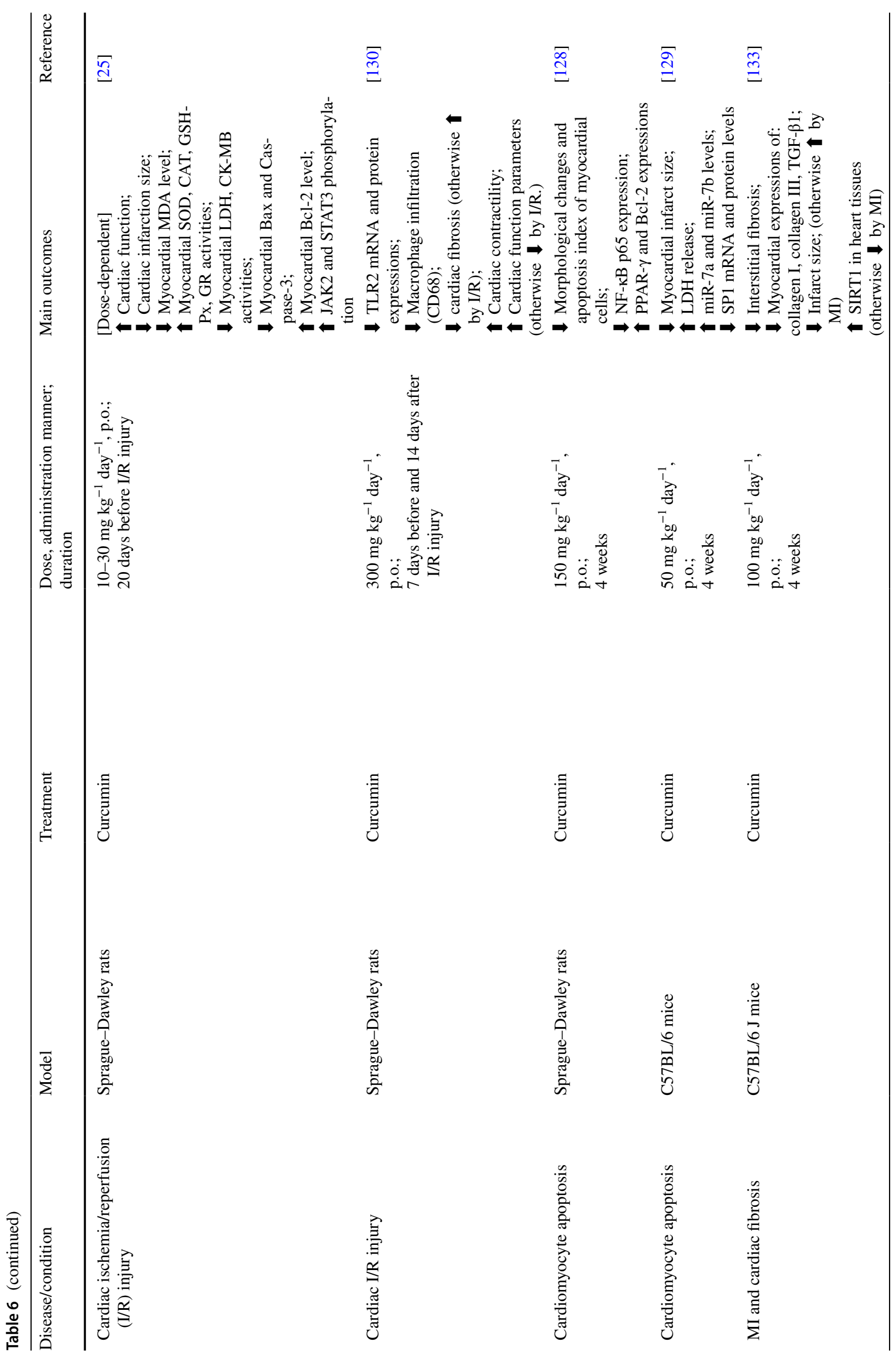




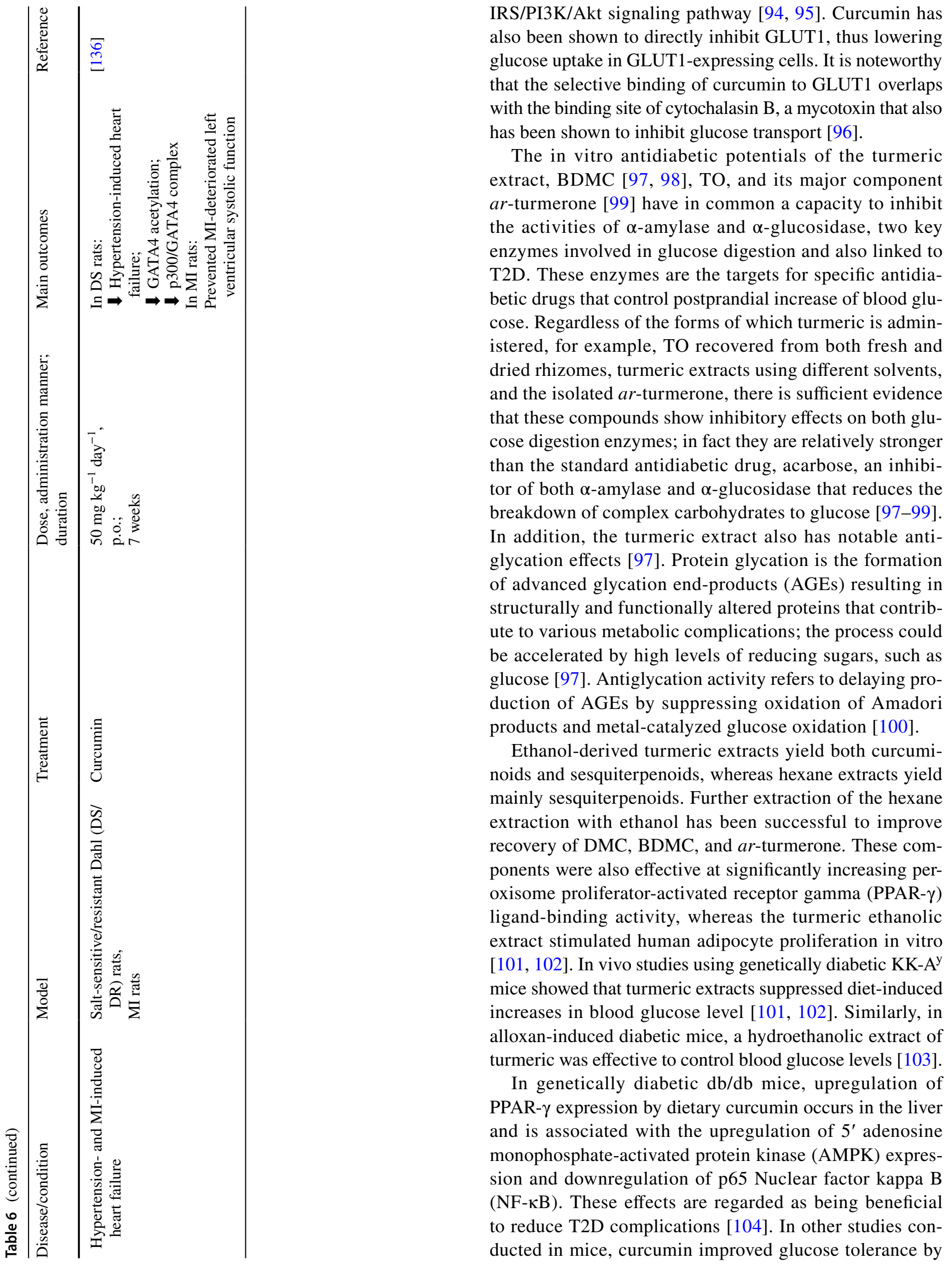


Table 7 Double-blind RCTs on antidiabetic and cardioprotective effects of turmeric and turmeric-derived bioactive compounds

\begin{tabular}{|c|c|c|c|c|c|c|}
\hline Disease/condition & $\begin{array}{l}\text { Sample population } \\
(n=\text { sample size })\end{array}$ & Duration & Treatment & $\begin{array}{l}\text { Dose, administration } \\
\text { manner }\end{array}$ & Outcome & Reference \\
\hline \multicolumn{7}{|l|}{ Diabetes } \\
\hline $\begin{array}{l}\text { Anthropometric } \\
\text { parameters and } \\
\text { serum lipid profile }\end{array}$ & $\begin{array}{l}\text { Hyperlipidemic T2D } \\
\text { patients }(n=72)\end{array}$ & 8 weeks & $\begin{array}{l}\text { Turmeric rhizome } \\
\text { powder }\end{array}$ & $2100 \mathrm{mg} \mathrm{day}^{-1}$, p.o & $\begin{array}{l}\text { Compared to baseline: } \\
\downarrow \text { Body weight; } \\
\downarrow \text { Serum TG; } \\
\downarrow \text { Serum LDL-c } \\
\text { Compared to control: } \\
\downarrow \text { BMI; } \\
\downarrow \text { Serum TG; } \\
\downarrow \text { Serum TC }\end{array}$ & [112] \\
\hline $\begin{array}{l}\text { Serum lipid profile } \\
\text { and inflammation } \\
\text { status }\end{array}$ & $\begin{array}{l}\text { T2D patients } \\
(n=44)\end{array}$ & 10 weeks & $\begin{array}{l}\text { Curcumin capsule } \\
\text { (69.4\% curcumin, } \\
16.8 \% \text { DMC, } 1.8 \% \\
\text { BDMC, and } 7.6 \% \\
\text { TO) }\end{array}$ & $1500 \mathrm{mg} \mathrm{day}^{-1}$, p.o & $\begin{array}{l}\text { Compared to baseline: } \\
\text { Serum TG } \\
\text { Compared to control: } \\
\downarrow \text { Serum hs-CRP }\end{array}$ & [113] \\
\hline Serum lipid profile & $\begin{array}{l}\text { T2D patients } \\
(n=118)\end{array}$ & 12 weeks & $\begin{array}{l}\text { Curcuminoids + pip- } \\
\text { erine }\end{array}$ & $\begin{array}{l}1000 \mathrm{mg} \mathrm{day}^{-1} \\
\text { curcumi- } \\
\text { noids }+10 \mathrm{mg} \mathrm{day}^{-1} \\
\text { piperine, } \\
\text { p.o }\end{array}$ & $\begin{array}{l}\text { Compared to control: } \\
\downarrow \text { Serum TC; } \\
\downarrow \text { Serum non-HDL-c; } \\
\downarrow \text { Serum Lp(a); } \\
\downarrow \text { Serum HDL-c }\end{array}$ & [114] \\
\hline $\begin{array}{l}\text { Diabetic sensorimo- } \\
\text { tor polyneuropathy } \\
\text { (DSPN) }\end{array}$ & $\begin{array}{l}\text { T2D patients } \\
(n=80)\end{array}$ & 8 weeks & Nano-curcumin & $80 \mathrm{mg} \mathrm{day}^{-1}$, p.o & $\begin{array}{l}\downarrow \text { Glycemic indices: } \\
\text { HbA1c, } \\
\text { FBS; } \\
\downarrow \text { DSPN severity: } \\
\text { total score of neuropa- } \\
\text { thy, } \\
\text { total symptom score, } \\
\text { total reflex score }\end{array}$ & [29] \\
\hline $\begin{array}{l}\text { Metabolic syndrome } \\
\text { (MetS) }\end{array}$ & $\begin{array}{l}\text { Apparently healthy } \\
\text { males screened posi- } \\
\text { tive for MetS } \\
(n=250)\end{array}$ & 8 weeks & Turmeric & $2.4 \mathrm{~g} \mathrm{day}^{-1}$, p.o & $\begin{array}{l}\text { At } 4 \text { weeks: } \\
\downarrow \mathrm{BMI} ; \\
1 \mathrm{WC} ; \\
1 \% \mathrm{BF} \\
\text { At } 8 \text { weeks: } \\
\downarrow \text { LDL-c; } \\
\text { CRP }\end{array}$ & [109] \\
\hline MetS & $\begin{array}{l}\text { Individuals with MetS } \\
\quad(n=120)\end{array}$ & 6 weeks & $\begin{array}{l}\text { Curcumin (native or } \\
\text { phospholipidated) }\end{array}$ & $1 \mathrm{~g} \mathrm{day}^{-1}$, p.o & $\begin{array}{l}\text { Serum PAB } \\
\text { (native curcumin, but } \\
\text { not phospholipidated } \\
\text { curcumin) }\end{array}$ & [18] \\
\hline MetS & $\begin{array}{l}\text { Individuals with MetS } \\
\quad(n=120)\end{array}$ & 6 weeks & $\begin{array}{l}\text { Curcumin (native or } \\
\text { phospholipidated) }\end{array}$ & $1 \mathrm{~g} \mathrm{day}^{-1}$, p.o & $\begin{array}{l}\text { No significant effects } \\
\text { on serum anti-Hsp } \\
27 \text { concentrations }\end{array}$ & [138] \\
\hline MetS & $\begin{array}{l}\text { Individuals with MetS } \\
\quad(n=120)\end{array}$ & 6 weeks & $\begin{array}{l}\text { Curcumin (native or } \\
\text { phospholipidated) }\end{array}$ & $1 \mathrm{~g} \mathrm{day}^{-1}$, p.o & $\begin{array}{l}\text { Serum } \mathrm{Zn} \text {; } \\
\text { Serum } \mathrm{Zn} / \mathrm{Cu} \text { ratio } \\
\text { Phospholipidated } \\
\text { curcumin resulted in } \\
\text { higher increases than } \\
\text { native curcumin }\end{array}$ & [110] \\
\hline MetS & $\begin{array}{l}\text { Individuals with MetS } \\
\quad(n=117)\end{array}$ & 8 weeks & $\begin{array}{l}\text { Curcuminoids + pip- } \\
\text { erine }\end{array}$ & $\begin{array}{l}1000 \mathrm{mg} \mathrm{day}^{-1} \\
\text { curcumi- } \\
\text { noids }+10 \mathrm{mg} \mathrm{day}^{-1} \\
\text { piperine, p.o }\end{array}$ & $\begin{array}{l}\text { 1 Serum SOD activ- } \\
\text { ity; } \\
\text { Serum MDA; } \\
\text { Serum CRP }\end{array}$ & [111] \\
\hline \multicolumn{7}{|l|}{ CVD } \\
\hline Atherogenic risk & $\begin{array}{l}\text { T2D patients } \\
(n=117)\end{array}$ & 6 months & Curcuminoid & $750 \mathrm{mg} \mathrm{day}^{-1}$, p.o & $\begin{array}{l}\text { Pulse wave veloc- } \\
\text { ity; } \\
\text { Serum leptin; } \\
\text { Serum adiponectin }\end{array}$ & [126] \\
\hline
\end{tabular}


Table 7 (continued)

\begin{tabular}{|c|c|c|c|c|c|c|}
\hline Disease/condition & $\begin{array}{l}\text { Sample population } \\
(n=\text { sample size })\end{array}$ & Duration & Treatment & $\begin{array}{l}\text { Dose, administration } \\
\text { manner }\end{array}$ & Outcome & Reference \\
\hline $\begin{array}{l}\text { Acute myocardial } \\
\text { infarction (MI) } \\
\text { associated with cor- } \\
\text { onary artery bypass } \\
\text { grafting (CABG) }\end{array}$ & $\begin{array}{l}\text { Patients undergoing } \\
\text { CABG without valve } \\
\text { surgery } \\
(n=121) \mathrm{z}\end{array}$ & 8 days & Curcuminoid & $4 \mathrm{~g} \mathrm{day}^{-1}$, p.o & $\begin{array}{l}\text { In-hospital MI } \\
\text { incidence; } \\
\downarrow \text { Postoperative levels } \\
\text { of: } \\
\text { CRP, } \\
\text { MDA, } \\
\text { NT-pro-BNP }\end{array}$ & [26] \\
\hline
\end{tabular}

stimulating secretion of the glucagon-like peptide-1 (GLP1), and also incretin from enteroendocrine L (GLUTag L) cells [31]. These activities are connected to the stimulated proliferation of $\beta$-cells and glucose-dependent insulin secretion, both of which are important for T2D treatment and prevention. Kato et al. [31] reported a similar finding regarding curcumin stimulation of GLP-1 secretion in GLUTag L cells in vitro. G-protein-coupled receptors (GPRs) are a group of free fatty acid receptors (FFARs) on the surface of $\beta$-cells, among which GPR 40 and GRP 120 are important for $\beta$-cells in the mediation of insulin secretion upon stimulation by long-chain fatty acids [105]. Both in vivo and in vitro studies have confirmed that activation of the GPR 40/120 pathway is involved in the GLP-1-stimulating effect of curcumin; this conclusion was reached by the observation that this effect was also reduced when cells were treated with GW1100, a GPR 40/120 antagonist [31].

Obesity is a major co-morbidity of T2D, and strategies that have been developed to treat this disorder by inhibiting the sterol regulatory element-binding protein (SREBP) pathway, important for regulating gene expressions that stimulate fatty acid, triacylglyceride, and cholesterol biosynthesis [106]. Ding et al. [107] reported that curcumin was an active inhibitor of triacylglyceride and cholesterol synthesis by downregulating expressions of both SREBP-1 and SREBP-2, respectively. Curcumin also has been shown to improve glucose homeostasis and insulin sensitivity by upregulating the phosphorylation of IRS-1, IRS-2, and Akt in these mice [107].

Metabolic syndrome (MetS), a term that refers to the co-occurrence of morbidities that increase the risk of heart attack, stroke, and T2D, engages several dysfunctional metabolic outcomes that include excess fat around the waist, insulin resistance, hyperglycemia, atherogenic dyslipidemia, and hypertension [108]. Randomized clinical trial (RCT) studies conducted with MetS subjects reported that turmeric, curcumin, and curcuminoids are effective at improving pertinent anthropometric and biochemical-metabolic parameters in these patients. Turmeric improves body mass index (BMI), waist circumference (WC), and the percent body fat (\%BF) and also lowers serum low-density lipoprotein cholesterol (LDL-c) and C-reactive protein (CRP) levels in MetS patients [109]. Curcumin significantly increases the serum pro-oxidant-antioxidant balance $(\mathrm{PAB})$ and the zinc-to-copper $(\mathrm{Zn} / \mathrm{Cu})$ ratio, and in addition will also increase serum $\mathrm{Zn} / \mathrm{Cu}$ ratios without affecting PAB $[18,110]$. Short-term supplementation with a curcuminoid-piperine combination also improves oxidative stress and inflammatory status in MetS patients, as evidenced by increased serum superoxide dismutase (SOD) activity and a decrease in serum malondialdehyde (MDA) and CRP levels [111]. Piperine, a pungent alkaloid recovered from black pepper, enhances bioavailability of curcuminoids [111]. The CRP-lowering effect observed in MetS patients fed various purified or standardized preparations of curcumin or curcuminoids leads to a final conclusion derived from a meta-analysis [111]. By alleviating MetS, turmeric and related curcuminoids actively prevented the development of T2D. Notwithstanding this, similar results that pointed to improved metabolic parameters due to curcumin treatment were also reported in patients with existing T2D. Three double-blind RCTs [112-114], involving 44 to 118 T2D patients supplemented with turmeric rhizome powder, a curcumin capsule consisting of curcuminoids and $\mathrm{TO}$, or a curcuminoid-piperine combination over an 8- to 12-week treatment duration, showed similar improvements in anthropometric parameters. These parameters included lowered body weight and BMI, and positive changes in serum lipid profiles that included reduced triglyceride (TG), total cholesterol (TC), LDL-c, and lipoprotein a [ $\mathrm{Lp}(\mathrm{a})]$, and increased high-density lipoprotein cholesterol (HDL-c). In addition, the inflammation status was amended by a reduction in serum high-sensitivity CRP levels [112-114]. A systematic review and meta-analysis of RCTs [115] has recently reported that curcumin or curcuminoids preparations are effective at lowering body weight and BMI in subjects with obesity or T2D. Nano-curcumin, a nano-formulation of curcumin with enhanced bioavailability, can also improve glycemic indices in T2D subjects. This finding was based on observed reductions in serum glycated hemoglobin (HbA1c) and fasting blood sugar (FBS), and improved severity of diabetic sensorimotor polyneuropathy (DSPN), known to be a common T2D complication [29]. Taken together, the data are very convincing as to the benefits of turmeric and curcumin to improve both the serum 


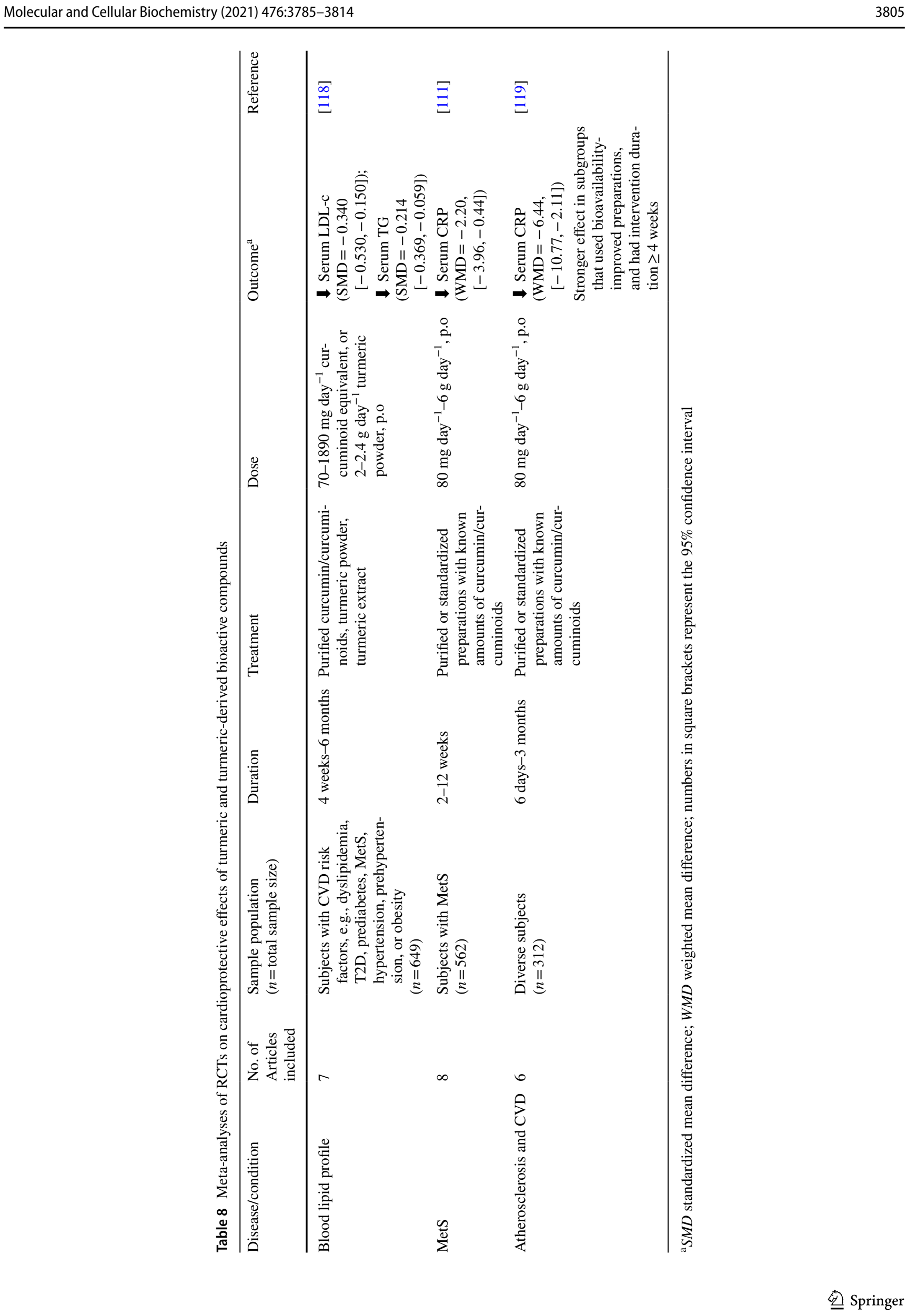


Fig. 4 Pancreatic $\beta$-cell signaling mechanisms involved in hypoglycemic and antidiabetic events attributed to curcumin (created with https://BioRender. com). Abbreviations are given below

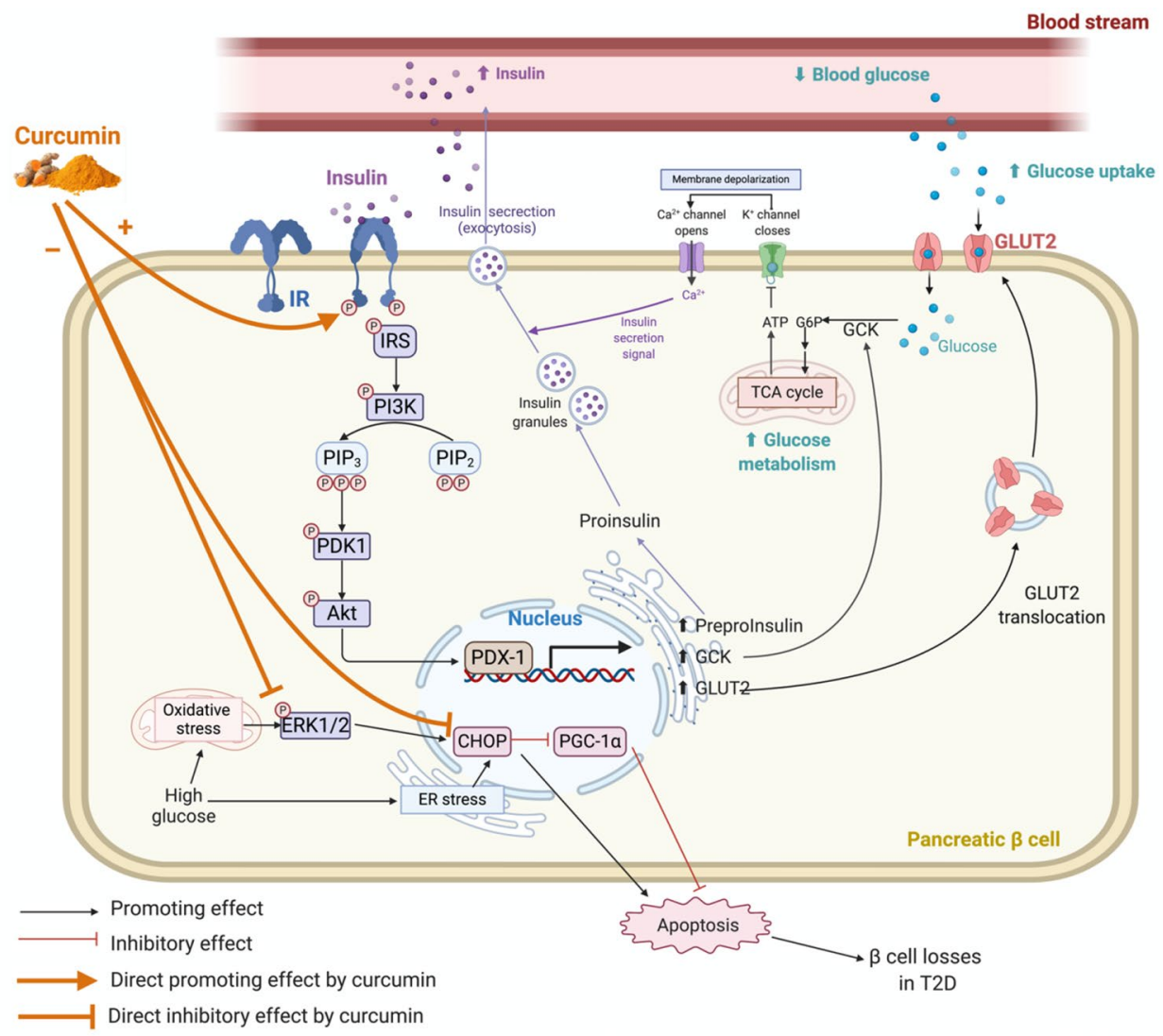

lipid profile, glycemic indices, hemoglobin glycation, and inflammatory conditions of T2D patients.

\section{Hypolipidemic, atheroprotective, and cardioprotective activities}

Studies conducted in vitro, in vivo, and also in human clinical trials have collected considerable evidence to indicate that turmeric and associated bioactive components, especially curcumin, can protect against CVD; albeit underlying mechanisms can differ (Fig. 5). A very strong line of evidence for protection has been attributed to the antioxidant and anti-inflammatory effects of curcumin that involve the regulation cell signaling pathways, such as mitogen-activated protein kinase (MAPK), NF- $\mathrm{KB}$, and nuclear factor erythroid 2-related factor 2-Kelch-like ECH-associated protein 1 (Nrf2-Keap1). These molecular redox signaling pathways combat oxidative stress and inflammation-two highly recognized factors associated with the etiology and pathogenesis of CVDs [116, 117]. In addition, the onset of MetS, as discussed previously in T2D subjects, is another risk factor for the development of CVD which curcumin was effective to mitigate. Of particular interest is that turmeric, curcumin, and curcuminoids are all effective in preventing CVD in both healthy individuals, as well as those individuals that have underlying CVD risk factors. The biomarkers that have been used to indicate these outcomes include reductions in serum LDL cholesterol, TG, and CRP [118, 119].

Atherosclerosis associated with CVD involves the narrowing or hardening of coronary arteries due to the deposition of cholesterol plaques initiated by an increase in serum oxidized low-density lipoproteins (oxLDL) [120]. Curcumin activates increased expression of low-density lipoprotein (LDL) receptors, both in cultured human liver cancer cell line HepG2 [121] and mouse macrophage [122], thus contributing to increased LDL uptake, an important step in protection against atherosclerosis. In the apolipoprotein $\mathrm{E}$ knockout (ApoE ${ }^{-/-}$) mouse model, dietary curcumin prevented the incidence and progression of atherosclerosis [27, 28, 123]. Coban et al. [123] reported that curcumin was effective at inducing significant changes in aortic gene expression, in particular those associated with monocyte adhesion to aortic endothelial cells and transmigration through to the aortic endothelium. Curcumin also downregulated the expression of vascular cell adhesion molecule-1 (VCAM-1) and intercellular cell adhesion molecule-1 (ICAM-1) in vitro [123] and in vivo [27]. VCAM-1 and ICAM-1 have important roles in the adhesion of monocytes to aortic endothelial cells in the early formation of atherosclerosis, and both are upregulated by NF- $\mathrm{KB}$ [124]. Correspondingly, curcumin increases inhibitor of NF- $\kappa \mathrm{B}(\mathrm{I} \kappa \mathrm{B})$ expression [123], while also decreasing NF- $\mathrm{KB}$ activation 


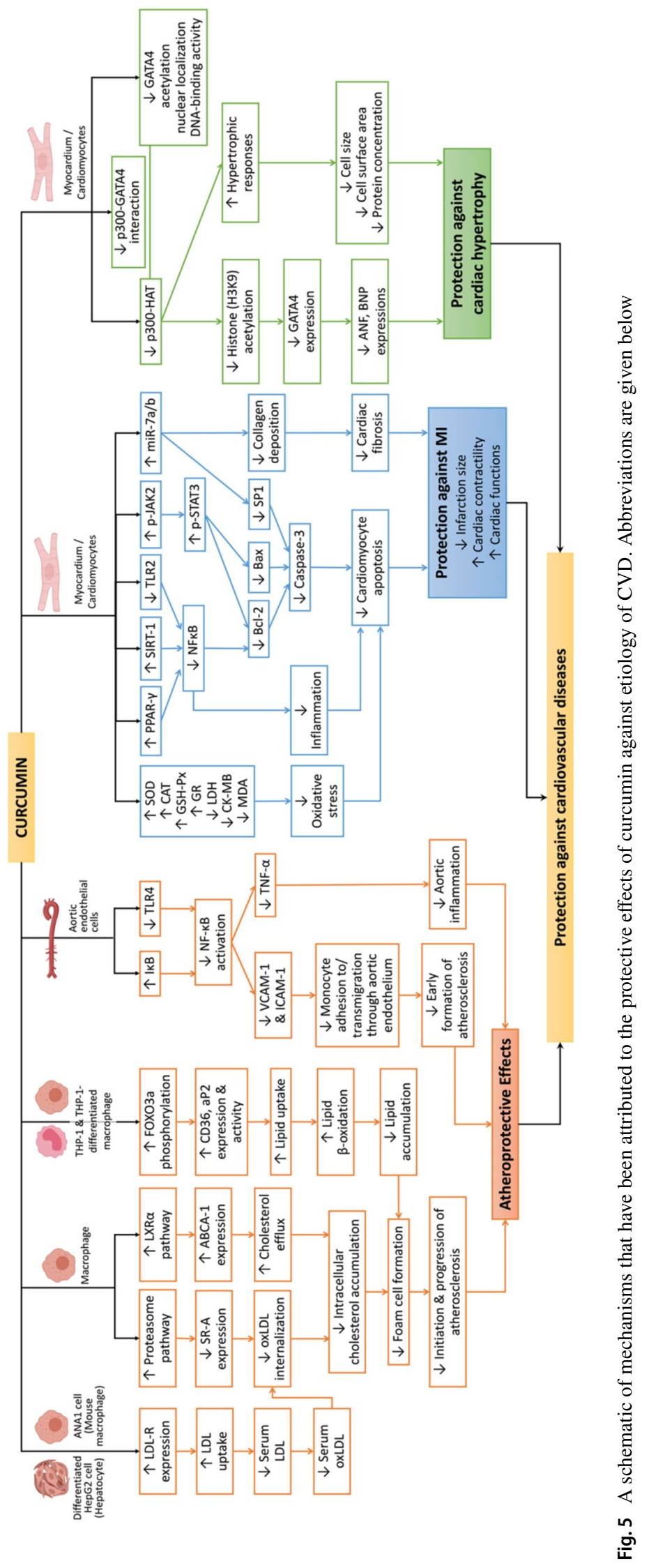


and tumor necrosis factor $\alpha$ (TNF- $\alpha)$ [27], in aortic tissue. Expression of toll-like receptor 4 (TLR4), an upstream mediator of NF- $\mathrm{KB}$, was shown to be suppressed by curcumin [27]. Serum levels of NF- $\kappa B$-associated inflammatory cytokines were also significantly reduced by curcumin treatment in $\mathrm{ApoE}^{-/-}$mice $[27,28]$. These researchers found that the atheroprotective capacity of curcumin was due to an affinity to reduce oxLDL-stimulated foam cell development, a crucial step in the initiation and progression of atherosclerosis. Curcumin suppresses intracellular cholesterol accumulation in macrophages by decreasing both oxLDL internalization and increasing cholesterol efflux. Furthermore, molecular studies revealed that these two effects are attributed to downregulation of scavenger receptor class A (SR-A) expression, via proteasome activation, and upregulation of adenosine triphosphate (ATP)-binding cassette transporter A1 (ABCA1) expression, via liver X receptor $\alpha$ (LXR $\alpha$ ) pathway, respectively [28].

The affinity of curcumin to upregulate Forkhead box O3a (FOXO3a) activity, a central transcription factor that regulates lipid transport genes in macrophage LDL, and recovered from LDL receptor knockout (LDL- ${ }^{--}$) mice fed a high-fat diet [125], is important for recognizing its potential role to prevent atherosclerosis. Curcumin improves the serum lipid profile of $\mathrm{ApoE}^{-/}$mice by reducing $\mathrm{TC}, \mathrm{TG}$, non-HDL-cholesterol, and increased HDL-cholesterol [28]. These activities correspond to an early retarded progression of atherosclerosis by alleviating oxidation and inflammation and by supporting cholesterol homeostasis through stabilizing the serum lipid profile and preventing endothelial dysfunction. Although human clinical trials designed to show the efficacy of curcumin/curcuminoids to treat atherosclerosis have not yet been established, a daily intake of curcuminoids at $750 \mathrm{mg}$ effectively reduced atherogenic risk in T2D patients in a 6-month double-blind RCT [126].

Myocardial infarction (MI) is frequently associated with underlying atherosclerotic conditions, due to a sudden diminished supply of oxygenated blood caused by narrowing of blood vessels [120]. Hong et al. [127], using an experimental MI rat model, demonstrated numerous benefits of curcumin that included significant protection of cardiac function and reduced cardiac infarction size. Connected with these observations were anti-inflammatory responses related to regulation of genes involved in cytokine-cytokine receptor interaction, extracellular matrix (ECM) receptor interaction, and Janus kinase (JAK)/signal transducer and activator of transcription (STAT) pathway [127]. In particular, the activation of JAK2/STAT3 signaling pathway by curcumin is associated with reduced infarction size in rats injured with cardiac ischemia/reperfusion (I/R) and curcumin induced reduction in oxidative stress, inflammation, and cardiomyocyte apoptosis [25]. The anti-apoptotic effect of curcumin on cardiomyocytes was also reported to be mediated through the downregulation of NF- $\mathrm{kB}$ expression and upregulation of expression PPAR- $\gamma$ and B-cell lymphoma-2 (Bcl-2), an apoptotic factor [128]. Others have reported that curcumin induced upregulation of microRNA-7a/b (miR-7a/b), while also downregulating specific protein 1 (SP1) [129]. Kim et al. [130] reported that curcumin was able to protect cardiac contractibility and cardiac function in I/R-injured rats, and this effect could be mediated by decreasing toll-like receptor 2 (TLR2) expression and macrophage infiltration. TLR2, a key mediator of the innate immune system, is involved in MI by activating the NF- $\mathrm{KB}$ pathway that results in cardiomyocyte inflammation and contractile dysfunction [131, 132]. An in vitro model of neonatal rat cardiomyocytes treated with curcumin confirmed the downregulation of TLR2 expression, when MI cells were challenged with hypoxia/reoxygenation $(\mathrm{H} / \mathrm{R})$ to mimic the in vivo $\mathrm{I} / \mathrm{R}$ process [130]. Post-MI cardiac fibrosis was prevented by curcumin, restoring MI-induced downregulation of nicotinamide adenine dinucleotide (NAD)-dependent deacetylase sirtuin-1 (SIRT-1) expression, and collagen deposition in heart tissues [133]. Taken together, these findings show that the capacity of curcumin to ameliorate MI and MI-induced injury is by attenuating oxidative stress, inflammatory status, cardiomyocyte apoptosis, and collagen deposition in the infarcted area, all of which contribute to a reduced infarction size and improved cardiac function. An RCT study reported that curcuminoid administration at $4 \mathrm{~g} \mathrm{day}^{-1}$ for 3 days before coronary artery bypass grafting (CABG) surgery and 5 days after the surgery, significantly reduced the incidence of in-hospital MI events associated with CABG [26]. In this study, postoperative levels of CRP, MDA, and N-terminal pro-B-type natriuretic peptide were also improved. These biomarkers indicate a direct involvement of antioxidant and anti-inflammatory effects of curcuminoids in the protection against CABG-associated MI. The efficacy of curcuminoids, or other turmeric bioactives, on prevention and treatment of MI in a more general population has not yet been established.

Cardiac hypertrophy is characterized by abnormal enlargement or thickening of heart muscle caused by increased cardiomyocyte size. The more intensive sarcomere is an adaptive response to hemodynamic stresses that results from various pro-hypertrophic stimuli [134]. Although it is compensatory to improve cardiac performance under a stress-induced condition, persisted hypertrophy can cause cardiac decompensation and contractile dysfunction, which will eventually lead to heart failure [134]. Curcumin, DMC, and BDMC have protective effects against cardiac hypertrophy, and one of the most critical mechanisms involves the inhibition of p300-specific histone acetyltransferase (HAT) activity [135]. p300-HAT is a transcriptional coactivator of several transcription factors, e.g., GATA-binding factor 4 (GATA4), critically important for both the development and 
differentiation of cardiomyocytes, which precede the progression of cardiac hypertrophy and heart failure. Indeed, histone acetylation is a notable transcriptional modification that mediate the activation of these transcription factors. Inhibition of p300-HAT activity was associated with reduced histone acetylation and hypertrophic responses in rat cardiomyocytes [135]. Curcumin, DMC, and BDMC had positive effects on p300-HAT inhibitory activity and anti-hypertrophic effects to a similar extent. In cardiomyocyte models, curcumin inhibited not only p300-HAT but also the nuclear localization and DNA-binding activity of GATA4 [136, 137], and p300-GATA4 interaction [136]. These effects were associated with repressed hypertrophic responses of the cardiomyocytes, and prevention of heart failure in both hypertension-induced and MI-induced heart failure rat models [136].

Associated with these protective effects of curcumin on molecular signaling of myocardial health is the observation that curcuminoid supplementation reduced circulating CRP levels, a chronic inflammatory biomarker that predicts risk to atherothrombosis and CVD in both normal healthy individuals and individuals with chronic health conditions [119]. However, more human clinical evidence for turmeric having protective and therapeutic efficacies against CVD, in particular, is needed. Furthermore, well-designed and longer-term RCTs with specific CVD outcome measures are required to confirm the potential health benefits of curcumin in lowering incidence of CVD.

\section{Conclusion}

This review summarized the complex chemical composition and specific bioactivities of turmeric and turmeric-derived constituents, such as curcumin, DMC, BMC, and TO. A focus was placed on describing cellular and molecular mechanisms that underlie the etiology and pathogenesis of diabetes, and CVD disorders, and how the protective properties of turmeric and its constituents can lessen these chronic disease conditions. Favorable results generated from human RCTs on the efficacies of these bioactives that mitigate risk factors for the aforementioned health conditions further support the use of turmeric constituents as ingredients in functional food and nutraceutical preparations. To fully evaluate the long-term preventative and therapeutic efficacies of these compounds, RCTs with subjects from a more general population, having longer intervention durations and a specific endpoint for reduction in disease outcomes are warranted.

Acknowledgements $\mathrm{HZ}$ was funded from a Natural Sciences and Engineering Research Council (NSERC) Discovery Grant to DDK [No. RGPIN2019-04130].

\section{References}

1. Kocaadam B, Şanlier N (2017) Curcumin, an active component of turmeric (Curcuma longa), and its effects on health. Crit Rev Food Sci Nutr 57(13):2889-2895. https://doi.org/10.1080/10408 398.2015.1077195

2. Nair KPP (2013) 1-turmeric: origin and history. In: Nair KPP (ed) The agronomy and economy of turmeric and ginger. Elsevier, Oxford, pp 1-5

3. Prasad S, Aggarwal BB (2011) Turmeric, the golden spice: from traditional medicine to modern medicine. In: Benzie IFF, Wachtel-Galor S (eds) Herbal medicine: biomolecular and clinical aspects, 2nd edn. CRC Press/Taylor \& Francis, Boca Raton, pp 263-288

4. Solymosi K, Latruffe N, Morant-Manceau A, Schoefs B (2015) 1 -food colour additives of natural origin. In: Scotter MJ (ed) Colour additives for foods and beverages. Woodhead Publishing Series in Food Science, Technology and Nutrition. Woodhead Publishing, Oxford, pp 3-34

5. Aggarwal BB, Sundaram C, Malani N, Ichikawa H (2007) Curcumin: the Indian solid gold. In: Aggarwal BB, Surh Y-J, Shishodia S (eds) The molecular targets and therapeutic uses of curcumin in health and disease. Advances in experimental medicine and biology. Springer US, Boston, pp 1-75. https:// doi.org/10.1007/978-0-387-46401-5 1

6. Portincasa P, Bonfrate L, Scribano MLL, Kohn A, Caporaso N, Festi D, Campanale MC, Di Rienzo T, Guarino M, Taddia M, Fogli MV, Grimaldi M, Gasbarrini A (2016) Curcumin and fennel essential oil improve symptoms and quality of life in patients with irritable bowel syndrome. J Gastrointest Liver Dis 25(2):151-157. https://doi.org/10.15403/jgld.2014.1121.252.ccm

7. Sanidad KZ, Sukamtoh E, Xiao H, McClements DJ, Zhang $G$ (2019) Curcumin: recent advances in the development of strategies to improve oral bioavailability. Annu Rev Food Sci Technol 10(1):597-617. https://doi.org/10.1146/annur ev-food-032818-121738

8. Verma RK, Kumari P, Maurya RK, Kumar V, Verma RB, Singh RK (2018) Medicinal properties of turmeric (Curcuma longa L.): a review. Int J Chem Stud 6(4):1354-1357

9. Smith T, Gillespie M, Eckl V, Knepper J, Reynolds CM (2019) Herbal supplement sales in US increase by $9.4 \%$ in 2018. Am Bot Counc. http://cms.herbalgram.org/herbalgram/issue123/files/ HG123-HMR.pdf. Accessed 03 Dec 2020

10. Emirik M (2020) Potential therapeutic effect of turmeric contents against SARS-CoV-2 compared with experimental COVID-19 therapies: in silico study. J Biomol Struct Dyn. https://doi.org/ 10.1080/07391102.2020.1835719

11. Valizadeh H, Abdolmohammadi-Vahid S, Danshina S, Ziya Gencer M, Ammari A, Sadeghi A, Roshangar L, Aslani S, Esmaeilzadeh A, Ghaebi M, Valizadeh S, Ahmadi M (2020) Nano-curcumin therapy, a promising method in modulating inflammatory cytokines in COVID-19 patients. Int Immunopharmacol 89(Pt B):107088. https://doi.org/10.1016/j.intimp.2020. 107088

12. Meng F-C, Zhou Y-Q, Ren D, Wang R, Wang C, Lin L-G, Zhang X-Q, Ye W-C, Zhang Q-W (2018) Chapter 10-turmeric: a review of its chemical composition, quality control, bioactivity, and pharmaceutical application. In: Grumezescu AM, Holban AM (eds) Natural and artificial flavoring agents and food dyes. Academic Press, Cambridge, pp 299-350. https://doi.org/10. 1016/B978-0-12-811518-3.00010-7

13. Amalraj A, Pius A, Gopi S, Gopi S (2017) Biological activities of curcuminoids, other biomolecules from turmeric and their derivatives—a review. J Tradit Complement Med 7(2):205-233. https://doi.org/10.1016/j.jtcme.2016.05.005 
14. Kunnumakkara AB, Bordoloi D, Padmavathi G, Monisha J, Roy NK, Prasad S, Aggarwal BB (2017) Curcumin, the golden nutraceutical: multitargeting for multiple chronic diseases. $\mathrm{Br}$ J Pharmacol 174(11):1325-1348. https://doi.org/10.1111/bph. 13621

15. Akter J, Hossain MA, Takara K, Islam MZ, Hou D-X (2019) Antioxidant activity of different species and varieties of turmeric (Curcuma spp): isolation of active compounds. Comp Biochem Physiol Part C: Toxicol Pharmacol 215:9-17. https://doi.org/10. 1016/j.cbpc.2018.09.002

16. Alizadeh M, Kheirouri S (2019) Curcumin reduces malondialdehyde and improves antioxidants in humans with diseased conditions: a comprehensive meta-analysis of randomized controlled trials. Biomedicine 9(4):10-22. https://doi.org/10.1051/bmden/ 2019090423

17. Dall'Acqua S, Stocchero M, Boschiero I, Schiavon M, Golob S, Uddin J, Voinovich D, Mammi S, Schievano E (2016) New findings on the in vivo antioxidant activity of Curcuma longa extract by an integrated 1H NMR and HPLC-MS metabolomic approach. Fitoterapia 109:125-131. https://doi.org/10.1016/j. fitote. 2015.12 .013

18. Ghazimoradi M, Saberi-Karimian M, Mohammadi F, Sahebkar A, Tavallaie S, Safarian H, Ferns GA, Ghayour-Mobarhan M, Moohebati M, Esmaeili H, Ahmadinejad M (2017) The effects of curcumin and curcumin-phospholipid complex on the cerum pro-oxidant-antioxidant balance in subjects with metabolic syndrome. Phytother Res 31(11):1715-1721. https://doi.org/10. 1002/ptr.5899

19. Edwards RL, Luis PB, Nakashima F, Kunihiro AG, Presley S-H, Funk JL, Schneider C (2020) Mechanistic differences in the inhibition of NF- $\mathrm{KB}$ by turmeric and its curcuminoid constituents. J Agric Food Chem 68(22):6154-6160. https://doi.org/10.1021/ acs.jafc.0c02607

20. Rana M, Reddy SS, Maurya P, Singh V, Chaturvedi S, Kaur K, Agarwal H, Ahmad H, Naqvi A, Dwivedi AK, Dikshit M, Barthwal MK (2015) Turmerone enriched standardized Curcuma longa extract alleviates LPS induced inflammation and cytokine production by regulating TLR4-IRAK1-ROS-MAPK-NFKB axis. J Funct Foods 16:152-163. https://doi.org/10.1016/j.jff. 2015.04.034

21. White CM, Pasupuleti V, Roman YM, Li Y, Hernandez AV (2019) Oral turmeric/curcumin effects on inflammatory markers in chronic inflammatory diseases: a systematic review and meta-analysis of randomized controlled trials. Pharmacol Res 146:104280. https://doi.org/10.1016/j.phrs.2019.104280

22. Fu M, Fu S, Ni S, Wang D, Hong T (2018) Inhibitory effects of bisdemethoxycurcumin on mast cell-mediated allergic diseases. Int Immunopharmacol 65:182-189. https://doi.org/10.1016/j. intimp.2018.10.005

23. Wu S, Xiao D (2016) Effect of curcumin on nasal symptoms and airflow in patients with perennial allergic rhinitis. Ann Allergy Asthma Immunol 117(6):697-702.e691. https://doi.org/10. 1016/j.anai.2016.09.427

24. Zhang N, Li H, Jia J, He M (2015) Anti-inflammatory effect of curcumin on mast cell-mediated allergic responses in ovalbumininduced allergic rhinitis mouse. Cell Immunol 298(1):88-95. https://doi.org/10.1016/j.cellimm.2015.09.010

25. Liu T, Zhang L, Joo D, Sun S-C (2017) NF-кB signaling in inflammation. Signal Transduct Target Ther 2(1):1-9. https:// doi.org/10.1038/sigtrans.2017.23

26. Wongcharoen W, Jai-aue S, Phrommintikul A, Nawarawong W, Woragidpoonpol S, Tepsuwan T, Sukonthasarn A, Apaijai N, Chattipakorn N (2012) Effects of curcuminoids on frequency of acute myocardial infarction after coronary artery bypass grafting. Am J Cardiol 110(1):40-44. https://doi.org/10.1016/j.amjcard. 2012.02.043
27. Zhang S, Zou J, Li P, Zheng X, Feng D (2018) Curcumin protects against atherosclerosis in apolipoprotein e-knockout mice by inhibiting toll-like receptor 4 expression. J Agric Food Chem 66(2):449-456. https://doi.org/10.1021/acs.jafc.7b04260

28. Zhao J-F, Ching L-C, Huang Y-C, Chen C-Y, Chiang A-N, Kou YR, Shyue S-K, Lee T-S (2012) Molecular mechanism of curcumin on the suppression of cholesterol accumulation in macrophage foam cells and atherosclerosis. Mol Nutr Food Res 56(5):691-701. https://doi.org/10.1002/mnfr.201100735

29. Asadi S, Gholami MS, Siassi F, Qorbani M, Khamoshian K, Sotoudeh G (2019) Nano curcumin supplementation reduced the severity of diabetic sensorimotor polyneuropathy in patients with type 2 diabetes mellitus: a randomized double-blind placebocontrolled clinical trial. Complement Ther Med 43:253-260. https://doi.org/10.1016/j.ctim.2019.02.014

30. Hou K, Chen Y, Zhu D, Chen G, Chen F, Xu N, Barakat K, Zheng J, Xie X, Chen R (2020) Curcumin inhibits high glucose oxidative stress and apoptosis in pancreatic beta cells via CHOP/PCG-1a and pERK1/2. Front Biosci (Landmark Ed) 25:1974-1984

31. Kato M, Nishikawa S, Ikehata A, Dochi K, Tani T, Takahashi T, Imaizumi A, Tsuda T (2017) Curcumin improves glucose tolerance via stimulation of glucagon-like peptide-1 secretion. Mol Nutr Food Res 61(3):1600471. https://doi.org/10.1002/mnfr. 201600471

32. Song Z, Wang H, Zhu L, Han M, Gao Y, Du Y, Wen Y (2015) Curcumin improves high glucose-induced INS-1 cell insulin resistance via activation of insulin signaling. Food Funct 6(2):461-469. https://doi.org/10.1039/C4FO00608A

33. Kuttikrishnan S, Siveen KS, Prabhu KS, Khan AQ, Ahmed EI, Akhtar S, Ali TA, Merhi M, Dermime S, Steinhoff M, Uddin S (2019) Curcumin induces apoptotic cell death via inhibition of PI3-kinase/AKT pathway in B-precursor acute lymphoblastic leukemia. Front Oncol. https://doi.org/10.3389/fonc.2019.00484

34. Li M, Yue GG-L, Tsui SK-W, Fung K-P, Lau CB-S (2018) Turmeric extract, with absorbable curcumin, has potent anti-metastatic effect in vitro and in vivo. Phytomedicine 46:131-141. https://doi.org/10.1016/j.phymed.2018.03.065

35. Ramasamy TS, Ayob AZ, Myint HHL, Thiagarajah S, Amini F (2015) Targeting colorectal cancer stem cells using curcumin and curcumin analogues: insights into the mechanism of the therapeutic efficacy. Cancer Cell Int 15:96. https://doi.org/10.1186/ s12935-015-0241-x

36. Wang X-P, Wang Q-X, Lin H-P, Chang N (2017) Anti-tumor bioactivities of curcumin on mice loaded with gastric carcinoma. Food Funct 8(9):3319-3326. https://doi.org/10.1039/c7fo00555e

37. Bhat A, Mahalakshmi AM, Ray B, Tuladhar S, Hediyal TA, Manthiannem E, Padamati J, Chandra R, Chidambaram SB, Sakharkar MK (2019) Benefits of curcumin in brain disorders. BioFactors 45(5):666-689. https://doi.org/10.1002/biof.1533

38. Forouzanfar F, Read MI, Barreto GE, Sahebkar A (2020) Neuroprotective effects of curcumin through autophagy modulation. IUBMB Life 72(4):652-664. https://doi.org/10.1002/iub.2209

39. Huang L, Chen C, Zhang X, Li X, Chen Z, Yang C, Liang X, Zhu G, Xu Z (2018) Neuroprotective effect of curcumin against cerebral ischemia-reperfusion via mediating autophagy and inflammation. J Mol Neurosc 64(1):129-139. https://doi.org/10.1007/ s12031-017-1006-X

40. Al-Karawi D, Al Mamoori DA, Tayyar Y (2016) The role of curcumin administration in patients with major depressive disorder: mini meta-analysis of clinical trials. Phytother Res 30(2):175183. https://doi.org/10.1002/ptr.5524

41. Ng QX, Koh SSH, Chan HW, Ho CYX (2017) Clinical use of curcumin in depression: a meta-analysis. J Am Med Dir Assoc 18(6):503-508. https://doi.org/10.1016/j.jamda.2016.12.071 
42. Wang Z, Zhang Q, Yuan L, Wang S, Liu L, Yang X, Li G, Liu $\mathrm{D}$ (2014) The effects of curcumin on depressive-like behavior in mice after lipopolysaccharide administration. Behav Brain Res 274:282-290. https://doi.org/10.1016/j.bbr.2014.08.018

43. Goodarzi R, Sabzian K, Shishehbor F, Mansoori A (2019) Does turmeric/curcumin supplementation improve serum alanine aminotransferase and aspartate aminotransferase levels in patients with nonalcoholic fatty liver disease? A systematic review and meta-analysis of randomized controlled trials. Phytother Res 33(3):561-570. https://doi.org/10.1002/ptr.6270

44. Khan H, Ullah H, Nabavi SM (2019) Mechanistic insights of hepatoprotective effects of curcumin: therapeutic updates and future prospects. Food Chem Toxicol 124:182-191. https://doi. org/10.1016/j.fct.2018.12.002

45. Naik RS, Mujumdar AM, Ghaskadbi S (2004) Protection of liver cells from ethanol cytotoxicity by curcumin in liver slice culture in vitro. J Ethnopharmacol 95(1):31-37. https://doi.org/10. 1016/j.jep.2004.06.032

46. World Health Organization (2018) The top 10 causes of death. https://www.who.int/news-room/fact-sheets/detail/the-top-10causes-of-death. Accessed 03 Dec 2020

47. Kotha RR, Luthria DL (2019) Curcumin: biological, pharmaceutical, nutraceutical, and analytical aspects. Molecules 24(16):2930. https://doi.org/10.3390/molecules24162930

48. Nelson KM, Dahlin JL, Bisson J, Graham J, Pauli GF, Walters MA (2017) The essential medicinal chemistry of curcumin. J Med Chem 60(5):1620-1637. https://doi.org/10.1021/acs. jmedchem.6b00975

49. Prasad S, Gupta SC, Tyagi AK, Aggarwal BB (2014) Curcumin, a component of golden spice: from bedside to bench and back. Biotechnol Adv 32(6):1053-1064. https://doi.org/ 10.1016/j.biotechadv.2014.04.004

50. Lee J, Jung Y, Shin J-H, Kim HK, Moon BC, Ryu DH, Hwang G-S (2014) Secondary metabolite profiling of Curcuma species grown at different locations using GC/TOF and UPLC/QTOF MS. Molecules 19(7):9535-9551. https://doi.org/10.3390/ molecules19079535

51. Jacob JN (2016) Chapter 4-comparative studies in relation to the structure and biochemical properties of the active compounds in the volatile and nonvolatile fractions of turmeric $(C$. longa) and ginger (Z. officinale). In: Atta-ur-Rahman (ed) Studies in natural products chemistry, vol 48. Elsevier, Amsterdam, Netherlands, pp 101-135. https://doi.org/10.1016/B978-0-44463602-7.00004-7

52. Masuda T, Jitoe A, Isobe J, Nakatani N, Yonemori S (1993) Anti-oxidative and anti-inflammatory curcumin-related phenolics from rhizomes of Curcuma domestica. Phytochemistry 32(6):1557-1560. https://doi.org/10.1016/0031-9422(93) 85179-U

53. Li W, Wang S, Feng J, Xiao Y, Xue X, Zhang H, Wang Y, Liang X (2009) Structure elucidation and NMR assignments for curcuminoids from the rhizomes of Curcuma longa. Magn Reson Chem 47(10):902-908. https://doi.org/10.1002/mrc. 2478

54. Dao TT, Nguyen PH, Won HK, Kim EH, Park J, Won BY, Oh WK (2012) Curcuminoids from Curcuma longa and their inhibitory activities on influenza A neuraminidases. Food Chem 134(1):21-28. https://doi.org/10.1016/j.foodchem.2012.02.015

55. Nakayama R, Tamura Y, Yamanaka H, Kikuzaki H, Nakatani N (1993) Two curcuminoid pigments from Curcuma domestica. Phytochemistry 33(2):501-502. https://doi.org/10.1016/00319422(93)85548-6

56. Kiuchi F, Goto Y, Sugimoto N, Akao N, Kondo K, Tsuda Y (1993) Nematocidal activity of turmeric: synergistic action of curcuminoids. Chem Pharm Bull 41(9):1640-1643. https://doi. org/10.1248/cpb. 41.1640
57. Shang Z-P, Xu L-L, Lu Y-Y, Guan M, Li D-Y, Le Z-Y, Bai Z-L, Qiao X, Ye M (2019) Advances in chemical constituents and quality control of turmeric. World J Tradit Chin Med 5(2):116. https://doi.org/10.4103/wjtcm.wjtcm_12_19

58. Priyadarsini KI (2014) The chemistry of curcumin: from extraction to therapeutic agent. Molecules 19(12):20091-20112. https://doi.org/10.3390/molecules191220091

59. Price LC, Buescher RW (1997) Kinetics of alkaline degradation of the food pigments curcumin and curcuminoids. J Food Sci 62(2):267-269. https://doi.org/10.1111/j.1365-2621.1997.tb039 82.x

60. Priyadarsini KI (2009) Photophysics, photochemistry and photobiology of curcumin: studies from organic solutions, bio-mimetics and living cells. J Photochem Photobiol C: Photochem Rev 10(2):81-95. https://doi.org/10.1016/j.jphotochemrev.2009.05. 001

61. Tønnesen HH, Karlsen J, van Henegouwen GB (1986) Studies on curcumin and curcuminoids VIII. Photochemical stability of curcumin. Z Lebensm Unters Forch 183(2):116-122. https://doi. org/10.1007/BF01041928

62. Sasaki H, Sunagawa Y, Takahashi K, Imaizumi A, Fukuda H, Hashimoto T, Wada H, Katanasaka Y, Kakeya H, Fujita M, Hasegawa K, Morimoto T (2011) Innovative preparation of curcumin for improved oral bioavailability. Biol Pharm Bull 34(5):660-665. https://doi.org/10.1248/bpb.34.660

63. Kharat M, Aberg J, Dai T, McClements DJ (2020) Comparison of emulsion and nanoemulsion delivery systems: the chemical stability of curcumin decreases as oil droplet size decreases. J Agric Food Chem 68(34):9205-9212. https://doi.org/10.1021/ acs.jafc.0c01877

64. Arvapalli DM, Sheardy AT, Allado K, Chevva H, Yin Z, Wei J (2020) Design of curcumin loaded carbon nanodots delivery system: enhanced bioavailability, release kinetics, and anticancer activity. ACS Appl Bio Mater 3(12):8776-8785. https://doi.org/ 10.1021/acsabm.0c01144

65. Suresh D, Srinivasan K (2007) Studies on the in vitro absorption of spice principles - curcumin, capsaicin and piperine in rat intestines. Food Chem Toxicol 45(8):1437-1442. https://doi.org/ 10.1016/j.fct.2007.02.002

66. Verma SP, Salamone E, Goldin B (1997) Curcumin and genistein, plant natural products, show synergistic inhibitory effects on the growth of human breast cancer MCF-7 cells induced by estrogenic pesticides. Biochem Biophys Res Commun 233(3):692-696. https://doi.org/10.1006/bbrc.1997.6527

67. Eckert RL, Crish JF, Efimova T, Balasubramanian S (2006) Opposing action of curcumin and green tea polyphenol in human keratinocytes. Mol Nutr Food Res 50(2):123-129. https://doi.org/ 10.1002/mnfr.200500125

68. Afzal A, Oriqat G, Khan MA, Jose J, Afzal M (2013) Chemistry and biochemistry of terpenoids from Curcuma and related species. J Biol Act Prod Nat 3(1):1-55. https://doi.org/10.1080/ 22311866.2013.782757

69. Golding BT, Pombo-Villar E (1992) Structures of $\alpha$ - and $\beta$-turmerone. J Chem Soc Perkin Trans 1(12):1519-1524. https:// doi.org/10.1039/P19920001519

70. Ferreira LAF, Henriques OB, Andreoni AAS, Vital GRF, Campos MMC, Habermehl GG, de Moraes VLG (1992) Antivenom and biological effects of ar-turmerone isolated from Curcuma longa (Zingiberaceae). Toxicon 30(10):1211-1218. https://doi. org/10.1016/0041-0101(92)90437-A

71. Jantan I, Saputri FC, Qaisar MN, Buang F (2012) Correlation between chemical composition of curcuma domestica and Curcuma xanthorrhiza and their antioxidant effect on human lowdensity lipoprotein oxidation. Evid Based Complement Altern Med. https://doi.org/10.1155/2012/438356 
72. Hwang K-W, Son D, Jo H-W, Kim CH, Seong KC, Moon J-K (2016) Levels of curcuminoid and essential oil compositions in turmerics (Curcuma longa L.) grown in Korea. Appl Biol Chem 59(2):209-215. https://doi.org/10.1007/s13765-016-0156-9

73. Liju VB, Jeena K, Kuttan R (2011) An evaluation of antioxidant, anti-inflammatory, and antinociceptive activities of essential oil from Curcuma longa L. Indian J Pharmacol 43(5):526-531. https://doi.org/10.4103/0253-7613.84961

74. Kiso Y, Suzuki Y, Oshima Y, Hikino H (1983) Stereostructure of curlone, a sesquiterpenoid of Curcuma longa rhizomes. Phytochemistry 22(2):596-597. https://doi.org/10.1016/0031-9422(83) 83057-X

75. Chen J-J, Tsai C-S, Hwang T-L, Shieh P-C, Chen J-F, Sung P-J (2010) Sesquiterpenes from the rhizome of Curcuma longa with inhibitory activity on superoxide generation and elastase release by neutrophils. Food Chem 119(3):974-980. https://doi.org/10. 1016/j.foodchem.2009.07.060

76. Braga MEM, Leal PF, Carvalho JE, Meireles MAA (2003) Comparison of yield, composition, and antioxidant activity of turmeric (Curcuma longa L.) extracts obtained using various techniques. J Agric Food Chem 51(22):6604-6611. https://doi. org/10.1021/jf0345550

77. Ferreira FD, Kemmelmeier C, Arrotéia CC, da Costa CL, Mallmann CA, Janeiro V, Ferreira FMD, Mossini SAG, Silva EL, Machinski M (2013) Inhibitory effect of the essential oil of Curcuma longa $\mathrm{L}$. and curcumin on aflatoxin production by Aspergillus flavus Link. Food Chem 136(2):789-793. https://doi.org/10. 1016/j.foodchem.2012.08.003

78. Li W, Feng J-T, Xiao Y-S, Wang Y-Q, Xue X-Y, Liang X-M (2009) Three novel terpenoids from the rhizomes of Curcuma longa. J Asian Nat Prod Res 11(6):569-575. https://doi.org/10. 1080/10286020902939182

79. Ohshiro M, Kuroyanagi M, Ueno A (1990) Structures of sesquiterpenes from Curcuma longa. Phytochemistry 29(7):2201-2205. https://doi.org/10.1016/0031-9422(90)83038-3

80. Li J, Wang H-F, Chen G, Huang S-D, Zhang W-Y, Hua H-M, Pei Y-H (2015) Structure determination of two new bisabolane-type sesquiterpenes from the rhizomes of Curcuma longa by NMR spectroscopy. Magn Reson Chem 53(7):536-538. https://doi.org/ $10.1002 / \mathrm{mrc} .4215$

81. Zhang W-Y, Wang H-F, Chen G, Zhang O, Bai S, Pei Y-H (2014) Two new bisabolane sesquiterpenoids from Curcuma longa. J Asian Nat Prod Res 16(3):271-274. https://doi.org/10.1080/ 10286020.2013.875010

82. Imai S, Morikiyo M, Furihata K, Hayakawa Y, Seto H (1990) Turmeronol $\mathrm{A}$ and turmeronol $\mathrm{B}$, new inhibitors of soybean lipoxygenase. Agric Biol Chem 54(9):2367-2371. https://doi. org/10.1080/00021369.1990.10870290

83. Zeng Y, Qiu F, Takahashi K, Liang J, Qu G, Yao X (2007) New sesquiterpenes and calebin derivatives from Curcuma longa. Chem Pharm Bull 55(6):940-943. https://doi.org/10.1248/cpb. 55.940

84. Wen J, Qiu T-Y, Yan X-J, Qiu F (2018) Four novel bisabolanetype sesquiterpenes from Curcuma longa. J Asian Nat Prod Res 20(10):928-933. https://doi.org/10.1080/10286020.2017.13677 69

85. Yuan T, Zhang C, Qiu C, Xia G, Wang F, Lin B, Li H, Chen L (2018) Chemical constituents from Curcuma longa $\mathrm{L}$. and their inhibitory effects of nitric oxide production. Nat Prod Res 32(16):1887-1892. https://doi.org/10.1080/14786419.2017. 1354185

86. Xu J, Ji F, Kang J, Wang H, Li S, Jin D-Q, Zhang Q, Sun H, Guo Y (2015) Absolute configurations and NO inhibitory activities of terpenoids from Curcuma longa. J Agric Food Chem 63(24):5805-5812. https://doi.org/10.1021/acs.jafc.5b01584
87. Del Prete D, Millán E, Pollastro F, Chianese G, Luciano P, Collado JA, Munoz E, Appendino G, Taglialatela-Scafati O (2016) Turmeric sesquiterpenoids: expeditious resolution, comparative bioactivity, and a new bicyclic turmeronoid. J Nat Prod 79(2):267-273. https://doi.org/10.1021/acs.jnatprod.5b00637

88. Awasthi PK, Dixit SC (2009) Chemical composition of Curcuma longa leaves and rhizome oil from the plains of Northern India. J Young Pharm 1(4):312. https://doi.org/10.4103/0975-1483. 59319

89. Lin X, Ji S, Li R, Dong Y, Qiao X, Hu H, Yang W, Guo D, Tu P, Ye M (2012) Terpecurcumins A-I from the rhizomes of Curcuma longa: absolute configuration and cytotoxic activity. J Nat Prod 75(12):2121-2131. https://doi.org/10.1021/np300551g

90. Lin X, Ji S, Qiao X, Hu H, Chen N, Dong Y, Huang Y, Guo D, Tu P, Ye M (2013) Density functional theory calculations in stereochemical determination of terpecurcumins $\mathrm{J}-\mathrm{W}$, cytotoxic terpene-conjugated curcuminoids from Curcuma longa L. J Org Chem 78(23):11835-11848. https://doi.org/10.1021/jo401859u

91. Qiao X, Lin X-h, Ji S, Zhang Z-x, Bo T, Guo D-a, Ye M (2016) Global profiling and novel structure discovery using multiple neutral loss/precursor ion scanning combined with substructure recognition and statistical analysis (MNPSS): characterization of terpene-conjugated curcuminoids in Curcuma longa as a case study. Anal Chem 88(1):703-710. https://doi.org/10.1021/ acs.analchem.5b02729

92. Xiao YC, Xie J, Yu M, Liu M, Ran J, Xi Z, Li W, Huang J (2011) Bisabocurcumin, a new skeleton curcuminoid from the rhizomes of Curcuma longa L. Chin Chem Lett 22(12):14571460. https://doi.org/10.1016/j.cclet.2011.09.002

93. Xiao YC, Lei J, Liu M, Yu M, Ran J, Xie J, Li W, Huang J (2012) Three new bisabolocurcumin ethers from the rhizomes of Curcuma longa L. Helv Chim Acta 95(2):327-332. https:// doi.org/10.1002/hlca.201100273

94. Tang Y, Chen A (2010) Curcumin prevents leptin raising glucose levels in hepatic stellate cells by blocking translocation of glucose transporter-4 and increasing glucokinase. Br J Pharmacol 161(5):1137-1149. https://doi.org/10.1111/j.1476-5381. 2010.00956.x

95. Zhang D, Zhang Y, Ye M, Ding Y, Tang Z, Li M, Zhou Y, Wang C (2016) Interference with Akt signaling pathway contributes curcumin-induced adipocyte insulin resistance. Mol Cell Endocrinol 429:1-9. https://doi.org/10.1016/j.mce.2016. 04.013

96. Gunnink LK, Alabi OD, Kuiper BD, Gunnink SM, Schuiteman SJ, Strohbehn LE, Hamilton KE, Wrobel KE, Louters LL (2016) Curcumin directly inhibits the transport activity of GLUT1. Biochimie 125:179-185. https://doi.org/10.1016/j.biochi.2016.03. 014

97. Lekshmi PC, Arimboor R, Nisha VM, Menon AN, Raghu KG (2014) In vitro antidiabetic and inhibitory potential of turmeric (Curcuma longa $\mathrm{L}$ ) rhizome against cellular and LDL oxidation and angiotensin converting enzyme. J Food Sci Technol 51(12):3910-3917. https://doi.org/10.1007/s13197-013-0953-7

98. Ponnusamy S, Zinjarde S, Bhargava S, Rajamohanan PR, RaviKumar A (2012) Discovering bisdemethoxycurcumin from Curcuma longa rhizome as a potent small molecule inhibitor of human pancreatic $\alpha$-amylase, a target for type- 2 diabetes. Food Chem 135(4):2638-2642. https://doi.org/10.1016/j.foodchem. 2012.06.110

99. Lekshmi PC, Arimboor R, Indulekha PS, Menon AN (2012) Turmeric (Curcuma longa L.) volatile oil inhibits key enzymes linked to type 2 diabetes. Int J Food Sci Nutr 63(7):832-834. https://doi.org/10.3109/09637486.2011.607156

100. Ramkissoon JS, Mahomoodally MF, Ahmed N, Subratty AH (2013) Antioxidant and anti-glycation activities correlates with phenolic composition of tropical medicinal herbs. Asian 
Pac J Trop Med 6(7):561-569. https://doi.org/10.1016/S19957645(13)60097-8

101. Kuroda M, Mimaki Y, Nishiyama T, Mae T, Kishida H, Tsukagawa M, Takahashi K, Kawada T, Nakagawa K, Kitahara M (2005) Hypoglycemic effects of turmeric (Curcuma longa L. rhizomes) on genetically diabetic KK-Ay mice. Biol Pharm Bull 28(5):937-939. https://doi.org/10.1248/bpb.28.937

102. Nishiyama T, Mae T, Kishida H, Tsukagawa M, Mimaki Y, Kuroda M, Sashida Y, Takahashi K, Kawada T, Nakagawa K, Kitahara M (2005) Curcuminoids and sesquiterpenoids in turmeric (Curcuma longa L.) suppress an increase in blood glucose level in type 2 diabetic KK-Ay mice. J Agric Food Chem 53(4):959-963. https://doi.org/10.1021/jf0483873

103. Mustafa SB, Akram M, Muhammad Asif H, Qayyum I, Hashmi AM, Munir N, Khan FS, Riaz M, Ahmad S (2019) Antihyperglycemic activity of hydroalcoholic extracts of selective medicinal plants Curcuma longa, Lavandula stoechas, Aegle marmelos, and Glycyrrhiza glabra and their polyherbal preparation in alloxaninduced diabetic mice. Dose-Response. https://doi.org/10.1177/ 1559325819852503

104. Jiménez-Flores LM, López-Briones S, Macías-Cervantes MH, Ramírez-Emiliano J, Pérez-Vázquez V (2014) A PPAR $\gamma$, $\mathrm{NF}-\kappa \mathrm{B}$ and AMPK-dependent mechanism may be involved in the beneficial effects of curcumin in the diabetic $\mathrm{db} / \mathrm{db}$ mice liver. Molecules 19(6):8289-8302. https://doi.org/10.3390/ molecules 19068289

105. Chen Y, Cruzat VF, Newsholme P (2016) Chapter 3- $\beta$-cell metabolism, insulin production and secretion: metabolic failure resulting in diabetes. In: Mauricio D (ed) Molecular nutrition and diabetes. Academic Press, San Diego, pp 29-40

106. Zhao X, Xiaoli ZH, Abdulla A, Yang EST, Wang Q, Ji J-Y, Pessin JE, Das BC, Yang F (2014) Inhibition of SREBP transcriptional activity by a boron-containing compound improves lipid homeostasis in diet-induced obesity. Diabetes 63(7):24642473. https://doi.org/10.2337/db13-0835

107. Ding L, Li J, Song B, Xiao X, Zhang B, Qi M, Huang W, Yang L, Wang Z (2016) Curcumin rescues high fat diet-induced obesity and insulin sensitivity in mice through regulating SREBP pathway. Toxicol Appl Pharmacol 304:99-109. https://doi.org/ 10.1016/j.taap.2016.05.011

108. Huang PL (2009) A comprehensive definition for metabolic syndrome. Dis Model Mech 2(5-6):231-237. https://doi.org/ 10.1242/dmm.001180

109. Amin F, Islam N, Anila N, Gilani AH (2015) Clinical efficacy of the co-administration of turmeric and black seeds (kalongi) in metabolic syndrome-a double blind randomized controlled trial-TAK-MetS trial. Complement Ther Med 23(2):165-174. https://doi.org/10.1016/j.ctim.2015.01.008

110. Safarian H, Parizadeh SMR, Saberi-Karimain M, Darroudi S, Javandoost A, Mohammadi F, Moammeri M, Ferns GA, Ghayour-Mobarhan M, Mohebati M (2019) The effect of curcumin on serum copper and zinc and $\mathrm{Zn} / \mathrm{Cu}$ ratio in individuals with metabolic syndrome: a double-blind clinical trial. J Diet Suppl 16(6):625-634. https://doi.org/10.1080/19390211.2018.14727 11

111. Panahi Y, Hosseini MS, Khalili N, Naimi E, Majeed M, Sahebkar A (2015) Antioxidant and anti-inflammatory effects of curcuminoid-piperine combination in subjects with metabolic syndrome: a randomized controlled trial and an updated meta-analysis. Clin Nutr 34(6):1101-1108. https://doi.org/10.1016/j.clnu.2014.12. 019

112. Adab Z, Eghtesadi S, Vafa M-R, Heydari I, Shojaii A, Haqqani H, Arablou T, Eghtesadi M (2019) Effect of turmeric on glycemic status, lipid profile, hs-CRP, and total antioxidant capacity in hyperlipidemic type 2 diabetes mellitus patients. Phytother Res 33(4):1173-1181. https://doi.org/10.1002/ptr.6312
113. Adibian M, Hodaei H, Nikpayam O, Sohrab G, Hekmatdoost A, Hedayati M (2019) The effects of curcumin supplementation on high-sensitivity C-reactive protein, serum adiponectin, and lipid profile in patients with type 2 diabetes: a randomized, doubleblind, placebo-controlled trial. Phytother Res 33(5):1374-1383. https://doi.org/10.1002/ptr.6328

114. Panahi Y, Khalili N, Sahebi E, Namazi S, Reiner Ž, Majeed M, Sahebkar A (2017) Curcuminoids modify lipid profile in type 2 diabetes mellitus: a randomized controlled trial. Complement Ther Med 33:1-5. https://doi.org/10.1016/j.ctim.2017.05.006

115. Mousavi SM, Milajerdi A, Varkaneh HK, Gorjipour MM, Esmaillzadeh A (2020) The effects of curcumin supplementation on body weight, body mass index and waist circumference: a systematic review and dose-response meta-analysis of randomized controlled trials. Crit Rev Food Sci Nutr 60(1):171-180. https:// doi.org/10.1080/10408398.2018.1517724

116. Banez MJ, Geluz MI, Chandra A, Hamdan T, Biswas OS, Bryan NS, Von Schwarz ER (2020) A systemic review on the antioxidant and anti-inflammatory effects of resveratrol, curcumin, and dietary nitric oxide supplementation on human cardiovascular health. Nutr Res 78:11-26. https://doi.org/10.1016/j.nutres.2020. 03.002

117. Li H, Sureda A, Devkota HP, Pittalà V, Barreca D, Silva AS, Tewari D, Xu S, Nabavi SM (2020) Curcumin, the golden spice in treating cardiovascular diseases. Biotechnol Adv 38:107343. https://doi.org/10.1016/j.biotechadv.2019.01.010

118. Qin S, Huang L, Gong J, Shen S, Huang J, Ren H, Hu H (2017) Efficacy and safety of turmeric and curcumin in lowering blood lipid levels in patients with cardiovascular risk factors: a metaanalysis of randomized controlled trials. Nutr J 16(1):68. https:// doi.org/10.1186/s12937-017-0293-y

119. Sahebkar A (2014) Are curcuminoids effective c-reactive protein-lowering agents in clinical practice? Evidence from a metaanalysis. Phytother Res 28(5):633-642. https://doi.org/10.1002/ ptr.5045

120. Patel SS, Acharya A, Ray RS, Agrawal R, Raghuwanshi R, Jain $P$ (2020) Cellular and molecular mechanisms of curcumin in prevention and treatment of disease. Crit Rev Food Sci Nutr 60(6):887-939. https://doi.org/10.1080/10408398.2018.1552244

121. Dou X, Fan C, Wo L, Yan J, Qian Y, Wo X (2008) Curcumin up-regulates LDL receptor expression via the sterol regulatory element pathway in HepG2 cells. Planta Med 74(11):1374-1379. https://doi.org/10.1055/s-2008-1081316

122. Fan C, Wo X, Qian Y, Yin J, Gao L (2006) Effect of curcumin on the expression of LDL receptor in mouse macrophages. J Ethnopharmacol 105(1):251-254. https://doi.org/10.1016/j.jep.2005.11. 009

123. Coban D, Milenkovic D, Chanet A, Khallou-Laschet J, Sabbe L, Palagani A, Berghe WV, Mazur A, Morand C (2012) Dietary curcumin inhibits atherosclerosis by affecting the expression of genes involved in leukocyte adhesion and transendothelial migration. Mol Nutr Food Res 56(8):1270-1281. https://doi.org/10. 1002/mnfr.201100818

124. Galkina E, Ley K (2007) Vascular adhesion molecules in atherosclerosis. Arterioscler Thromb Vasc Biol 27(11):2292-2301. https://doi.org/10.1161/ATVBAHA.107.149179

125. Zingg J-M, Hasan ST, Cowan D, Ricciarelli R, Azzi A, Meydani M (2012) Regulatory effects of curcumin on lipid accumulation in monocytes/macrophages. J Cell Biochem 113(3):833-840. https://doi.org/10.1002/jcb.23411

126. Chuengsamarn S, Rattanamongkolgul S, Phonrat B, Tungtrongchitr R, Jirawatnotai S (2014) Reduction of atherogenic risk in patients with type 2 diabetes by curcuminoid extract: a randomized controlled trial. J Nutr Biochem 25(2):144-150. https://doi.org/10.1016/j.jnutbio.2013.09.013 
127. Hong D, Zeng X, Xu W, Ma J, Tong Y, Chen Y (2010) Altered profiles of gene expression in curcumin-treated rats with experimentally induced myocardial infarction. Pharmacol Res 61(2):142-148. https://doi.org/10.1016/j.phrs.2009.08.009

128. Lv F-H, Yin H-L, He Y-Q, Wu H-M, Kong J, Chai X-Y, Zhang S-R (2016) Effects of curcumin on the apoptosis of cardiomyocytes and the expression of NF-кB, PPAR- $\gamma$ and Bcl-2 in rats with myocardial infarction injury. Exp Ther Med 12(6):38773884. https://doi.org/10.3892/etm.2016.3858

129. Geng H-H, Li R, Su Y-M, Xiao J, Pan M, Cai X-X, Ji X-P (2016) The circular RNA Cdr1as promotes myocardial infarction by mediating the regulation of miR-7a on its target genes expression. PLoS ONE 11(3):e0151753. https://doi.org/10.1371/journ al.pone. 0151753

130. Kim YS, Kwon JS, Cho YK, Jeong MH, Cho JG, Park JC, Kang JC, Ahn Y (2012) Curcumin reduces the cardiac ischemia-reperfusion injury: involvement of the toll-like receptor 2 in cardiomyocytes. J Nutr Biochem 23(11):1514-1523. https://doi.org/10. 1016/j.jnutbio.2011.10.004

131. Boyd JH, Mathur S, Wang Y, Bateman RM, Walley KR (2006) Toll-like receptor stimulation in cardiomyoctes decreases contractility and initiates an NF- $\mathrm{KB}$ dependent inflammatory response. Cardiovasc Res 72(3):384-393. https://doi.org/10. 1016/j.cardiores.2006.09.011

132. Zhu X, Bagchi A, Zhao H, Kirschning CJ, Hajjar RJ, Chao W, Hellman J, Schmidt U (2007) Toll-like receptor 2 activation by bacterial peptidoglycan-associated lipoprotein activates cardiomyocyte inflammation and contractile dysfunction. Crit Care Med 35(3):886-892. https://doi.org/10.1097/01.CCM.00002 56723.37586.A2

133. Xiao J, Sheng X, Zhang X, Guo M, Ji X (2016) Curcumin protects against myocardial infarction-induced cardiac fibrosis via SIRT1 activation in vivo and in vitro. Drug Des Dev Ther 10:1267-1277. https://doi.org/10.2147/DDDT.S104925

134. Samak M, Fatullayev J, Sabashnikov A, Zeriouh M, Schmack B, Farag M, Popov A-F, Dohmen PM, Choi Y-H, Wahlers T, Weymann A (2016) Cardiac hypertrophy: an introduction to molecular and cellular basis. Med Sci Monit Basic Res 22:75-79. https://doi.org/10.12659/MSMBR.900437

135. Sunagawa Y, Funamoto M, Sono S, Shimizu K, Shimizu S, Genpei M, Miyazaki Y, Katanasaka Y, Morimoto E, Ueno M, Komiyama M, Kakeya H, Wada H, Hasegawa K, Morimoto T (2018) Curcumin and its demethoxy derivatives possess p300 HAT inhibitory activity and suppress hypertrophic responses in cardiomyocytes. J Pharmacol Sci 136(4):212-217. https://doi. org/10.1016/j.jphs.2017.12.013

136. Morimoto T, Sunagawa Y, Kawamura T, Takaya T, Wada H, Nagasawa A, Komeda M, Fujita M, Shimatsu A, Kita T, Hasegawa K (2008) The dietary compound curcumin inhibits p300 histone acetyltransferase activity and prevents heart failure in rats. J Clin Investig 118(3):868-878. https://doi.org/10.1172/ JCI33160

137. Ahuja S, Kohli S, Krishnan S, Dogra D, Sharma D, Rani V (2011) Curcumin: a potential therapeutic polyphenol, prevents noradrenaline-induced hypertrophy in rat cardiac myocytes. J Pharm Pharmacol 63(12):1604-1612. https://doi.org/10.1111/j. 2042-7158.2011.01363.x

138. Mohammadi F, Ghazi-Moradi M, Ghayour-Mobarhan M, Esmaeili H, Moohebati M, Saberi-Karimian M, Safarian H, Tavallaie S, Ferns GA, Sahebkar A (2019) The effects of curcumin on serum heat shock protein 27 antibody titers in patients with metabolic syndrome. J Diet Suppl 16(5):592-601. https://doi.org/ 10.1080/19390211.2018.1472710

Publisher's Note Springer Nature remains neutral with regard to jurisdictional claims in published maps and institutional affiliations. 